\title{
Working Environment and Well-Being: Empirical Evidence from the 5th European Working Condition Survey
}

\author{
Lukas Schrott $^{1,2,3}$, Diana Moosbrugger ${ }^{2} \&$ Anna Iwanowa $^{3}$ \\ ${ }^{1}$ Department of Economics and Statistics, University of Innsbruck, Innsbruck, Austria \\ ${ }^{2}$ Department of Business and Technic, University of Applied Sciences Kufstein, Kufstein, Austria \\ ${ }^{3}$ Department of Psychology, University of Innsbruck, Innsbruck, Austria \\ Correspondence: Lukas Schrott, Department of Business and Technic, University of Applied Sciences Kufstein, \\ Andreas Hofer-Straße 7, 6330 Kufstein, Austria. Supported by the Tiroler Wissenschaftsfonds TWF
}

Received: September 28, 2015

Accepted: October 14, 2015

Available online: March 1, 2016

doi:10.11114/aef.v3i2.1429

URL: http://dx.doi.org/10.11114/aef.v3i2.1429

\begin{abstract}
The main aim of the paper is the definition of the constructs well-being, demands, resources and flexibility out of an existing and available data set. For this purpose we used the 5th European Working Conditions Survey, the theoretical assumptions from the Job Demands-Resources model (JD-R model) and further theoretical and empirical findings. Thus, we gained more information out of the data structure and the interdependence of the constructs, their dimensions and further explanatory variables as gender, work-life-balance, work-health-attitude, financial ease and type of contract. We also found interesting geographical pattern in the distribution of constructs. Hence, well-being is rather high in the northern part of West Europe and in North Europe. The resources, which affects well-being positive, are high in North Europe, while in South Europe they are low. Interestingly, also high demands with a negative influence on well-being, are found in the northern part of West Europe for the United Kingdom and Ireland. Flexibility is clearly high in North Europe and rather medium in the other countries. Thereby, overall flexibility is neutral concerning well-being, whereas the impact in the individual case can be positive as well as negative. Resources and demands are significant for employees well-being.
\end{abstract}

Keywords: well-being, resources, demands, flexibility, labor, human resources, working conditions, European Union

\section{Introduction}

\subsection{Relevance of the topic}

Our working environment and the social structures are changing. Hence, we observe an increased use of computer-, communication- and multimedia technologies as well, as changes in the employment organization. Thereby, new activities and jobs are created and other revived. Teamwork, just-in-time, lean production, new forms of interfirm cooperation, outsourcing and new forms of employment are only examples of these changes. As a result, some jobs become more and others less complex. Also the conditions for the companies are in transformation. Globalization, individual product requirements and a tougher competition are only some aspects with which the companies are confronted. More often hierarchical structures are replaced by flexible, agile organizations. Skills, innovation and quality standards become more important and decide on the future of industries, businesses and the labor force (see Tims, Bakker \& Derks, 2013; Iwanowa, 2012; Tangian, 2007 and Benach, Amable, Muntaner \& Benavides, 2002). Also Origo \& Pagani (2009) conclude, that the intensification of competitive pressures in recent decades has required more flexibility for both firms and workers.

Meissner (1971) analysis about "the long arm of the job" and the impact of the job on leisure time activities are often used as slogan to describe these impact on many other domains of life and sides the person: on their health and wellbeing, on the maintenance and using of intellectual faculties and use of cognitive capacity, on the way parents educate their children and on the attitudes, norms and values (see Meissner, 1971 and Ulich, 2011). Also May \& May (2004) summarize that work and occupation are essential for individual self-actualization, vitality, social productivity and recognition, also to raise its self-esteem and to become satisfied. Numerous research results point out the relationship between job characteristics, work organization and health (e.g. Semmer \& Mohr, 2001; Mohr \& Semmer, 
2002 and Ulich \& Wülser, 2004). Research in the specific area of occupational and organizational psychology, occupational health psychology, identifies two broad components of the work environment that are related to employee health and well-being: job demands and job resources (see Schaufeli \& Bakker, 2004).

There exist many models for explanation of the relationship between job characteristics and mental health of the employees e.g. Job Demand Control Support Model (Karasek \& Theorell, 1980), the Effort Reward Imbalance Theory (Siegrist, 1996) or the Job Demand Resources Model (Demerouti \& Bakker, 2011). These models have been tested in many studies and some of them have supported the models; others have not. Hence, Bödeker, Friedel, Röttger \& Schröer (2002) indicated that the work-related proportion of incapacity for work is ascribable to $29 \%$ to physical and to $31 \%$ to psychological demands (in 1998 for Germany). Lundberg et al. (1994) proved the relationship between stress and musculoskeletal complaints. Also Frauendorf, Caffier, Kaul \& Wawrzinoszek (1995) found a positive and significant correlation between time pressure and an increase in the bioelectrical activity of the shoulder muscles. Also low social encouragement, monotony and a lack of relaxation breaks lead to shoulder and neck pains (see Maintz, Ullsperger, Junghanss \& Ertel, 2000). Levi (2002) emphasizes that stress is a significant factor for the occurrence of depressive moods. And other research results confirm the relationship between depression and cardiovascular diseases (see Mayer, 2003; Penninx et al., 2001; Lederbogen, Deuschle \& Heuser, 1999 and Rundel \& Wise, 1996). Iwanowa (2006, 2004 and 2000) found significant coherences between high resources and positive emotions, better recovery, high(er) job satisfaction, less psychosomatic complaints as well as less depressive states. She also found significant coherences between high demands and negative emotions, poor recovery, passivity as well as higher psychosomatic complaints. Furthermore, a prolonged exposure to high job demands often coincides with reduced well-being (see Tims et. al., 2013) and if job demands continuously draw upon employees resources (and there is insufficient time to replenish them) employees will develop a strong need for recovery (see Demerouti, Bakker \& Fried, 2012). On the other side, the job resources have a favorable effect on well-being (see Tims et al., 2013). Therefore, when job resources increases, job satisfaction, work engagement and intrinsic motivation also tend to increase (Tims et al., 2013, p. 232). Demerouti \& Bakker (2011) added that the best job performance is shown in challenging, resourceful work environments, because such environments facilitate the work engagement. Also Holman (2011) stated that one of the main beneficial outcomes of a high quality of job is typically considered to be a high level of employee well-being. Furthermore, this influences quit rates and absence rates, which can also be viewed as beneficial outcomes of high quality jobs on the organizational level (see Holman, 2011; Griffeth, Hom \& Gärtner, 2000) (Note 1).

The main problem for the verification of the models is that not only that the samples are very different, but also that the investigation methods and the operationalization of the main dimensions, resources and stressors, are very variable. Sometimes the collected empirical data for resources concern e.g. job autonomy as job decision latitude, performance feedback, social support from colleagues or the supervisor, decision involvement, socio-moral climate etc. Demands are measured as role ambiguity, role conflict, role stress, stressful events, workload, work pressure, insecurity, organizational problems etc. Employee health is measured as burnout, psychosomatic complains, somatic health complaints, including sleep disturbance, headaches, respiratory infections, and gastrointestinal infection, depressive mood, increased prevalence of depressive and anxiety disorders, alcohol and drugs/substance dependence, poor somatic health and increased sickness absence. On the other hand well-being is operationalized as life and job satisfaction, engagement, intrinsic motivation, enthusiasm etc.

\subsection{Research Question}

Because the resources, the demands and the level of flexibility influence employees well-being and health, we are interested to gain more information about the distribution, the characteristics and the interdependence of well-being, demands, resources and flexibility in Europe. In doing so, we are able to (i) evaluate aspects of the working conditions in a cross-country approach, (ii) monitor the current state of well-being, resources, demands and flexibility as well, as aspects of their interdependence and (iii) this forms the basis to analyze convergence/divergence.

Under these aspects, our goal is to define several composite indices for every employee, characterizing the degree of well-being, demands, resources and flexibility of his/her work out of an existing and available data set. For this purpose we use the data out of the 5th European Working Conditions Survey (EWCS, see chapter 2.2), the theoretical assumption from the JD-R model (see chapter 2.1), the findings of Tangian (2007) and the considerations of Klau \& Mittelstadt (1989).

\subsection{Summary of the research activities based on the EWCS}

The focus of the research activities based on the 4th and 5th EuropeanWorking Condition Survey (EWCS) is on health, well-being, (flexible) working hours, job- and employment-quality, precarity, satisfaction and work-life-balance.

Based on the EWCS and other available data sets (e.g. European Quality of Life Survey, European Social Survey) the European Foundation for the Improvement of Living and Working Conditions (Eurofound) published a variety of 
analyses in the context to working hours, work-life-balance, life course perspective, health, well-being, economic sectors and gender perspectives (see Eurofound, 2012, 2012a, 2012b, 2009 and 2007). Also Smith, Burchell, Fagan \& O'Brien (2008), Leschke \& Watt (2008) and Greenan, Kalugina \& Walkowiak (2012 and 2010) used the EWCS for their research focused on labor-, employment- and job-quality. Cottini \& Lucifora (2010) as well as Poggi (2010) put their efforts to gain more information about the working conditions and their impact on mental health and well-being (see Cottini \& Lucifora, 2010) as well as their interdependence between aspirations and job satisfaction (see Poggi, 2010). Puig-Barrachina et al. (2013) give their attention to aspects and measurement of precarity and their social distribution. Lorenz \& Lundvall (2011) focused on creative aspects of the work in Europe. Detailed analyses in the context of the 4th wave of the EWCS did Tangian (2009, 2007 and 2007a). There, he focused on aspects of decent and precarious work as well as on flexibility.

The structure of the paper is as follows. Section two presents the methodological frameworks including a short overview of the JD-R model, the description of the used data set, the model specification, the used analysis methods and the hypotheses. Section three presents the empirical results including several robustness checks. A discussion of the limitations of the study, directions of future research and concluding remarks are offered in the final section.

\section{Methodology and Specification}

\subsection{The JD-R model}

The Job Demands-Resources model (JD-R) forms an important basis for our analyses. The JD-R model is a theoretical framework that tries to integrate two fairly independent research traditions: (i) the stress research tradition and the (ii) motivation research tradition (Demerouti \& Bakker, 2011, p. 1). According to the JD-R model, job demands lead to health impairment processes and job resources to motivational processes (Demerouti \& Bakker, 2011, p. 1), which include different specific demands and resources, depending on the context under study (Xanthopoulou, Bakker, Demerouti \& Schaufeli, 2007, p. 122).

Following Xanthopoulou et al. (2007) the job demands are those physical, social or organizational aspects of the job that require sustained physical and/or psychological costs (e.g. high work pressure, role overload, poor environmental conditions and problems related to reorganization (Bakker, Demerouti, Boer \& Schaufeli, 2003, p. 341), role conflict and role ambiguity (Demerouti \& Bakker, 2011, p. 4). Xanthapoulou et al. (2007) explain, that job resources are those physical, social or organizational aspects of the job that (i) are functional in achieving work-related goals, (ii) reduce job demands and the associated physiological and psychological costs, and (iii) stimulate personal growth and development. For that matter the resources may be located at the level of the organization (e.g. pay, career, support, team climate), at the level of the organization of work (e.g. role clarity, participation in decision making) and the task level (e.g. performance feedback, skill variety, task significance, task identity, autonomy) (Bakker et al., 2003, p. 344/345).

So high job demands, which require sustained effort, may exhaust employees resources and lead to energy depletion and health problems (Xanthopoulou et al., 2007, p. 122) or burnout (Bakker et al., 2003, p. 345). Furthermore Xanthapoulou et al. (2007) wrote, that job resources lead to organizational commitment and work engagement. Hence, a good job design is by limiting the job demands and increasing job resources (see Demerouti \& Bakker, 2011).

While demands are always associated with physical and/or psychical costs (which can be reduced by resources) and resources are clearly associated with a positive impact on well-being, we find other aspects of work which affect our well-being in a more complex way. Thus, we find in our data set distinct aspects of flexibility (as a independent construct), which can be positive or negative for employees well-being, depending on the arrangement and the autonomy of decision (Note 2). Therefore we extend our model by the construct of flexibility. This also allows us the presentation of flexibilization in Europe and represents our data set in a more detailed form.

\subsection{Data}

To study employee's well-being, resources, demands and flexibility across countries, we use the European Working Condition Survey (EWCS) as data source. The EWCS is a repeated cross-sectional survey of precarious employment, leadership styles, work participation, job context, working time, work organization, pay, work-related health risks, cognitive and psychosocial factors, work-life-balance and access to training. So it includes several objective and subjective aspects to capture working conditions, health and safety matters, quality of working life and well-being (Note $3)$.

The fifth wave was conducted in 2010, and includes a total of 34 countries namely the EU27, Norway, Croatia, the former Yugoslav Republic of Macedonia, Turkey, Albania, Montenegro and Kosovo. Thus, almost 44,000 workers were interviewed. The sample used in the EWCS is representative of those aged 15 years and over (16 and over in Spain, the UK and Norway) who are in employment and are resident in the country that is being surveyed. In each country the interviewed persons were selected by the method of random walk. The target number of interviews was 1,000 in all countries, except Slovenia $(1,400)$, the UK, Italy and Poland $(1,500)$, Germany and Turkey $(2,000)$, France $(3,000)$ and 
Belgium $(4,000)$. For each country the number of completed interviews reached at least the expected target numbers.

For our analysis, only employees are retained. Trainees, self-employed and unemployed are excluded and so the number of persons considered is thereby reduced to 35,187. Unfortunately, the survey includes questions with the answer options of "DK/No opinion" and "Refusal", so that these are considered as missings. In the end our sample consists of 28,876 employees out from 34 countries. With a mean of 849 observations (at a minimum of 305 observations in Albania and a maximum of 2,930 observations in Belgium). We found no systematic bias for questions which are answered as "DK/No opinion" or "Refusal". Even after omitting the missings, several robustness checks suggest that our results are comparable and consistent.

\subsection{Specification}

The selection of the appropriate questions was done in a multi-stage process. First of all we used theoretical explanations from the JD-R model and the RRS model (Resources-Requirements-Stressors Model; Iwanowa, 2004) to identify and select all questions that conform to the definition of the constructs demands and resources. Furthermore, we follow Tangian (2007) and Klau \& Mittelstadt (1989) to identify the questions which help to specify flexibility. Well-being was defined as a combination of subjective and objective factors that cover basic human needs, ensure somatic and psychological health and satisfaction (see Bliesener et al., 2009).

Unfortunately, the response options differ in their scale. We find nominally scaled and dichotomous response options. To make them comparable it is necessary to recode the variables. Hence, we recode each answer to 0 and 1 , so that in each case a low value means low well-being, resources, demands and flexibility and a high value means high wellbeing, resources, demands and flexibility. By recoding and aggregation, the possible construct values are also between 0 and 1 (see chapter 3). The full list and the (re)coding of the used questions for dimensions and constructs is detailed shown in the appendix.

Figure 1 shows the aggregation for the constructs and figure 2 illustrates the data structure of the model. Our 4 constructs (well-being, demands, resources and flexibility) consist of 15 dimensions and these consist of 93 questions. Each construct is calculated by it's dimensions mean and each dimension is calculated by the mean of it's questions. In figure 2 the first row shows the specified 4 constructs and the second row their particular dimensions. The used questions, to specify the dimensions, are shown exemplarily.

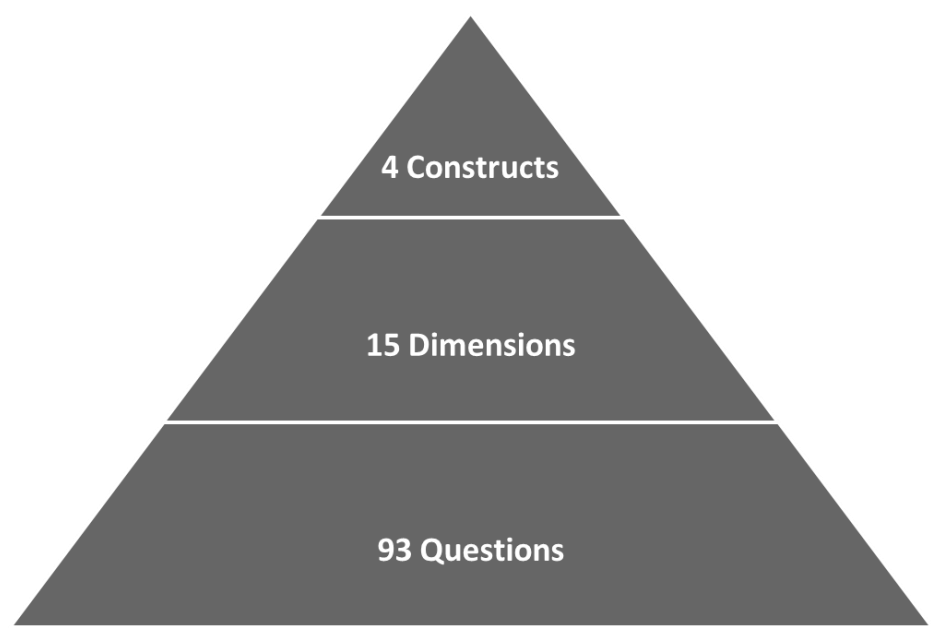

Figure 1. Model specification 


\begin{tabular}{|c|c|c|c|c|c|c|c|c|c|c|c|c|c|c|}
\hline \multicolumn{3}{|c|}{ Well-Being } & \multicolumn{3}{|c|}{ Resources } & \multicolumn{7}{|c|}{ Demands } & \multicolumn{2}{|c|}{ Flexibility } \\
\hline Physical health & Somatic health & Satisfaction & $\begin{array}{l}\text { Social support } \\
\text { \& Participation }\end{array}$ & $\ldots$ & $\ldots$ & Workplace & \begin{tabular}{|l|}
$\ldots$ \\
\end{tabular} & ... & ... & $\ldots$ & $\ldots$ & ... & \begin{tabular}{|l|} 
Numerical \\
\end{tabular} & Wage \\
\hline $\begin{array}{l}\text { q68: How is } \\
\text { your health in } \\
\text { general? } \\
\text { q69a: Did you } \\
\text { suffer from } \\
\text { hearing } \\
\text { problems }\end{array}$ & $\ldots$ & ... & $\ldots$ & $\ldots$ & ... & ... & ... & $\ldots$ & $\ldots$ & ... & $\ldots$ & $\ldots$ & $\ldots$ & $\ldots$ \\
\hline ... & & & & & & & & & & & & & & \\
\hline$\ldots$ & $\ldots$ & $\ldots$ & $\ldots$ & $\ldots$ & $\ldots$ & $\ldots$ & \begin{tabular}{|l|}
... \\
\end{tabular} & $\ldots$ & $\ldots$ & $\ldots$ & $\ldots$ & $\ldots$ & $\ldots$ & $\ldots$ \\
\hline$\ldots$ & $\ldots$ & $\ldots$ & $\ldots$ & $\ldots$ & $\ldots$ & $\ldots$ & $\ldots$ & $\ldots$ & $\ldots$ & $\ldots$ & $\ldots$ & $\ldots$ & $\ldots$ & $\ldots$ \\
\hline$\cdots$ & $\ldots$ & $\ldots$ & $\ldots$ & $\ldots$ & $\ldots$ & $\ldots$ & ... & $\cdots$ & $\ldots$ & $\cdots$ & $\cdots$ & & $\ldots$ & $\ldots$ \\
\hline
\end{tabular}

Figure 2. Data structure of model specification

As illustrated by the specification, we focus on the aggregate level of our constructs. So we can also compare the overall values (qualities) of well-being, resources, demands and flexibility as well, as their differences between (e.g.) countries, gender and work-life-balance. However, this implies that we make no statements about specific job factors or individuals, but we still explain some aspects of the interdependence between well-being, resources, demands and flexibility and their dimensions. If an aggregation like in our case is necessary, it is essential to discuss the weighting because the weighting can shift the statement in the aggregated form (see Holman, 2011). In the decision how to weight them, we follow Tangian (2007, p. 19). He argue, that the summation of the recoded items of the individual answers should be performed with equal weights (with reservation for the creation of the dimensions which implies a different weighting due to reasons of specification). The reasons which he stated are still valid to our model: (i) unequal weights need special motivation and we have none, (ii) if certain questions get higher weights then the opinions of those for whom these questions are of particular importance are overrepresented and (iii) it is a statistical tradition to accept the equal distribution (weights) by default, unless no other information is available (and we have no other theoretical or empirical robust information). At once this assumption of the equal weights satisfies the principle of maximal likelihood (Tangian, 2007, p. 19).

Based on theoretical assumptions from the JD-R model, the findings of Tangian (2007) and the considerations of Klau \& Mittelstadt (1989), we can identify 106 questions which appear plausible for the specification for our 4 constructs. In the next step, we performe a simple correlation analysis with these questions and exclude each question with a correlation $<0.1$ (Note 4). With the remaining 103 questions, we conduct the principal component factor analysis to test, improve and finalize our specification. Finally, our 4 constructs are specified by 93 questions. Overall, we achieve a Cronbach's alpha (Note 5) for the construct well-being in the amount of 0.828 , for resources 0.793 , for demands 0.765 and for the construct flexibility 0.676 .

\subsection{Methodology}

We examine the interdependence of our variables (constructs and dimensions) by an ordinary least square estimation. So we get information about the overall interdependence as well as about the interdependence of our dimensions. Furthermore, we use a common panel data model, the Least Square Dummy Variable Model (LSDV) to control for selected group effects. We group our sample by gender (hh2a), work-life-balance (q41), work-health-attitude (q67), financial ease/security (ef6), type of contract (q7) and countries (countid). All this group effects are fixed effects, which assume differences in intercepts across our groups. So in the case of heterogeneity in the units (the groups), an unbiased estimation of the coefficient is possible. Another advantage is that these effects do not cause an omitted variable bias (see Kennedy, 2003). Thereby, we ensure that we measure the influencing factors of the occurrences in the variables and not some other group effects. That is why our model is specified as follows in equation (1),

$$
w b_{i j}=\beta_{0}+\alpha_{j}+\beta_{1} r_{i j}+\beta_{2} d_{i j}+\beta_{3} f_{i j}+e_{i j}
$$

where $w b_{i j}$ is the well-being of individuum $i$ in group $j, \beta_{0}$ is the intercept (the conditional mean value of the reference category), $\alpha_{j}$ are the fixed group effects, $r_{i j}$ are the resources of individuum $i$ in group $j, d_{i j}$ are the demands of individuum $i$ in group $j, f_{i j}$ stands for the flexibility of individuum $i$ in group $j$ and $e_{i j}$ means the error term. To ensure that the estimator is unbiased, efficient and consistent, we also test for heteroscedasticity, multicolinearity and normal distribution. 
For a more comprehensive overview, we also show descriptive statistics and apply GIS analysis to reveal the geographical distribution of well-being, resources, demands and flexibility.

\subsection{Hypotheses}

Based on the literature and the findings in chapter 1 and 2, we formulate the following hypotheses:

- Due to the fact that resources are those aspects of work which can reduce job demands, stimulate personal growth and development and support the achievement of professional goals, we assume that resources have a positive influence on employees well-being (see e.g. Xanthopoulou et al., 2007).

- Because job demands are those physical, social or organizational aspects of the job, that require sustained physical and/or psychological costs, we assume that demands have a negative influence on employees well-being (see e.g. Xanthopoulou et al., 2007).

- The effect of flexibility strongly depends on the specific level of flexibilization, the arrangement of the flexible working-conditions and the self-determination about the extent and manner of flexibility. In the aggregated form we are only able to measure the "overall flexibility". In this context, we assume that the overall flexibility has nearly no, or if so, only a slightly negative influence on employees well-being (see e.g. Tangian, 2007).

- In society and work, we often find a gender gap between men and women. Under this aspects, we assume that we also find a negative gender gap in well-being for women.

- Also a higher financial ease/security will lead to a higher well-being. Financial ease/security stands for the possibilities to satisfy material as well as immaterial needs, and thus, measures the ability to enjoy a comfortable standard of living (see Porter \& Purser, 2008).

- The work-life-balance (the balance between work and leisure) strongly affects our well-being (see e.g. Bliesener et al., 2009). In this sense, we assume that a positive work-life-balance leads to a higher well-being.

- Furthermore we assume that if the employees believe that work affects their health in a negative way, then their well-being is significant lower (self-fulfilling prophecy).

- Atypical employment relationships are often associated with a higher precarity or a lower well-being (see e.g. Origio \& Pagani, 2009; Tangian, 2007; Keller \& Seifert, 2006). Under these aspects, we assume that the type of contract has an influence on well-being. Thereby a higher well-being is assumed for employees in typical employment relationships.

\section{Main Results}

Table 1 shows the summary statistics for our constructs. As mentioned, the theoretical range of each construct is between 0 and 1 . The average well-being score is 0.717 and reaches values between 0 and 1 with a standard deviation of 0.176 . The mean level of resources is 0.601 with a standard deviation of 0.206 . The spread of demands is between 0 and 0.943 , with a mean of 0.357 and a standard deviation of 0.161 . The mean level of flexibility is 0.208 with a standard deviation of 0.205 . In comparison to its mean, well-being has the lowest standard deviation, followed by resources and demands, while flexibility exhibits the largest heterogeneity.

Table 1. Summary statistics

\begin{tabular}{cccccc}
\hline Construct & Mean & Std.Dev. & Min. & Max. & N \\
\hline Well-being & 0.717 & 0.176 & 0 & 1 & 28,876 \\
Resources & 0.601 & 0.206 & 0 & 1 & 29,793 \\
Demands & 0.357 & 0.161 & 0 & 0.943 & 29,566 \\
Flexibility & 0.208 & 0.205 & 0 & 1 & 32,766 \\
\hline
\end{tabular}

The correlations of our constructs are presented in table 2. Concerning well-being, we find a weak positive correlation with resources (0.334) and negative ones with demands (-0.289). Nearly no correlation is found between flexibility and well-being (-0.030). Also between resources and demands, there is no correlation found (0.010). The resources and flexibility show nearly no correlation, with a correlation coefficient of 0.141 . And the correlation between flexibility and demands is also weak (0.302). The positive correlation between well-being and resources as well as the negative correlation between well-being and demands is consistent with the theory of the JD-R model. It is of interest, that the flexibility hardly correlate with the resources, while we find a (weak) positive correlation with the demands. Under this aspects, it seems to be necessary to improve the flexicurity approach to allow both employers and employees to benefit from flexibility. 
Table 2. Correlations

\begin{tabular}{lcccc}
\hline & Well-being & Resources & Demands & Flexibility \\
\hline Well-being & 1.000 & & & \\
Resources & 0.334 & 1.000 & & \\
Demands & -0.289 & 0.010 & 1.000 & \\
Flexibility & -0.030 & 0.141 & 0.302 & 1.000 \\
\hline
\end{tabular}

Figure 3 presents the distribution of the constructs. While resources and demands are almost normally distributed, well-being seems to be slightly left skewed and the flexibility is clearly right skewed. This is not surprising because our data also show that most of the employees work in traditional employment relationships with low flexibility.

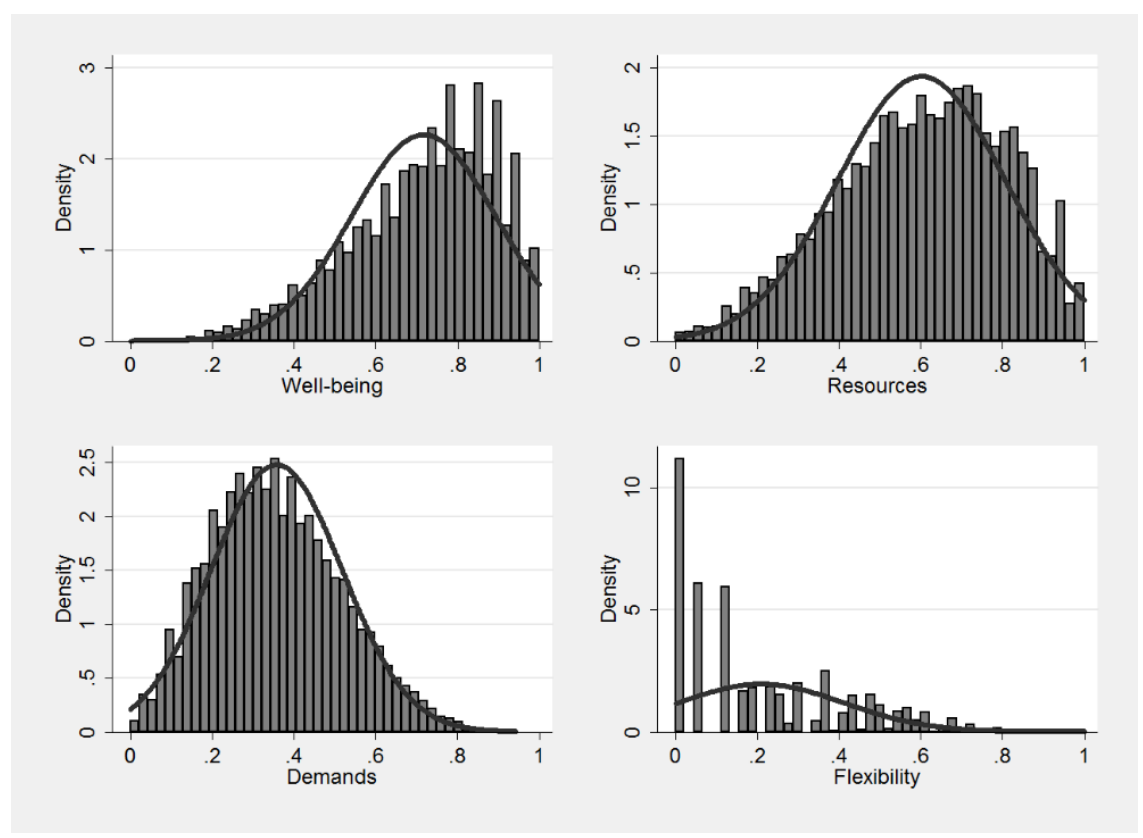

Figure 3. Distribution

For clustering the observed countries are divided into three categories low, medium and high, we follow the assumption that the construct values are normally distributed. This means that the middle $68.27 \%$ are classified as medium and values below as low and values above as high. Figure 4 presents the corresponding GIS results for those clusters for well-being, figure 5 for resources, figure 6 for demands and figure 7 for flexibility, while table 3 reports the ranking of the countries by well-being and the reached mean values of our four constructs in each country.

Predominantly, we find the highest well-being (figure 4) in North Europe and the northern part of West Europe. Hence, high well-being is found for Norway, Denmark, the United Kindom and Ireland. Also in Malta and Kosovo the employees have a high well-being. The lowest well-being is found for Lithuania, Latvia, Estonia, Hungary (which are located to the former eastern boundary to East Europe) and Czech Republic. Also low well-being is found for Turkey.

If we focus on resources (figure 5), we find high resources in the North European states Denmark, Norway and Finland and also for the Netherlands, which is located in the northern part of West Europe. Also high resources are found for Malta. The states with the lowest resources are Turkey, Montenegro and Greece.

With respect to the demands (figure 6), high demands have Turkey, Finland, Slovenia, Greece, the United Kingdom and Ireland. Surprisingly, in the United Kingdom and Ireland the demands as well as the well-being are high, but the resources are medium and in the Netherlands the demands are low and the resources are high, but well-being is medium. Low demands are found for Poland, Bulgaria, Italy, Albania, Netherlands and Latvia.

The distribution of the flexibility shows an interesting geographic pattern. As shown in figure 7 the states in North Europe (Finland, Denmark, Sweden and Norway) are clearly high flexible. Low flexibility is found for Cyprus, Portugal and Albania. 
Well-being

VIA not observed

$\square$ low $(<0.66)$

$\square$ medium (0.66 - 0.76)

high (>0.76)

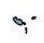

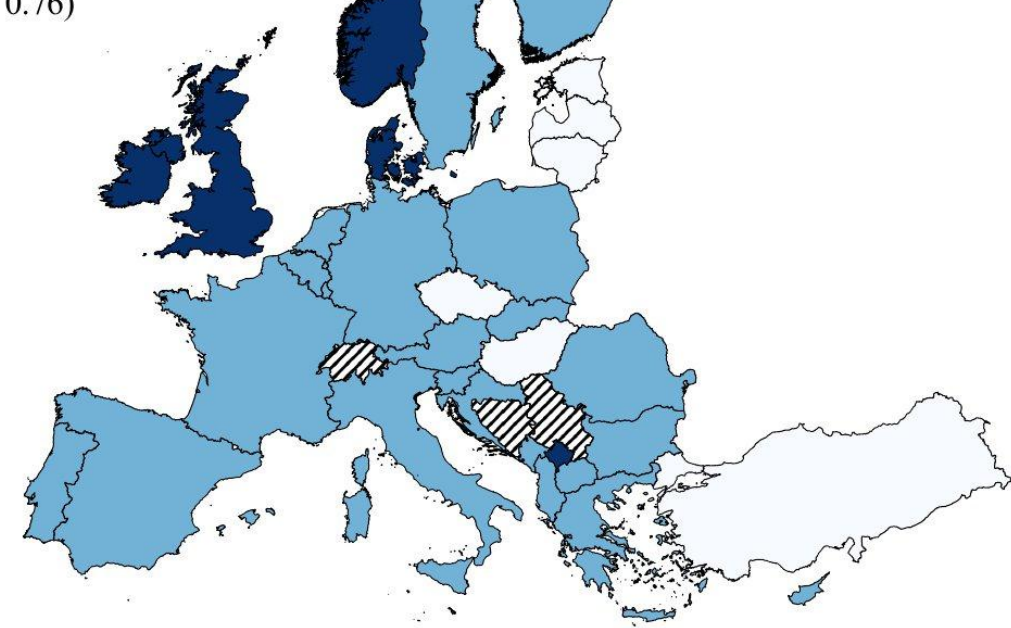

Figure 4. Well-being 2010

\section{Resources}

WIA not observed

$\square$ low $(<0.53)$

$\square$ medium $(0.53-0.67)$

- high (>0.67)

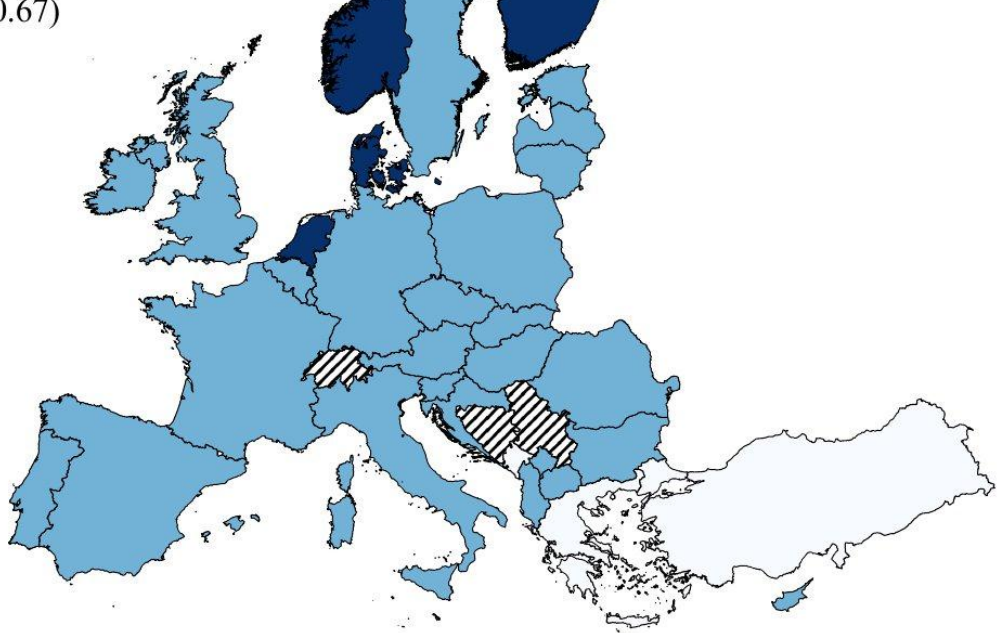

Figure 5. Resources 2010 


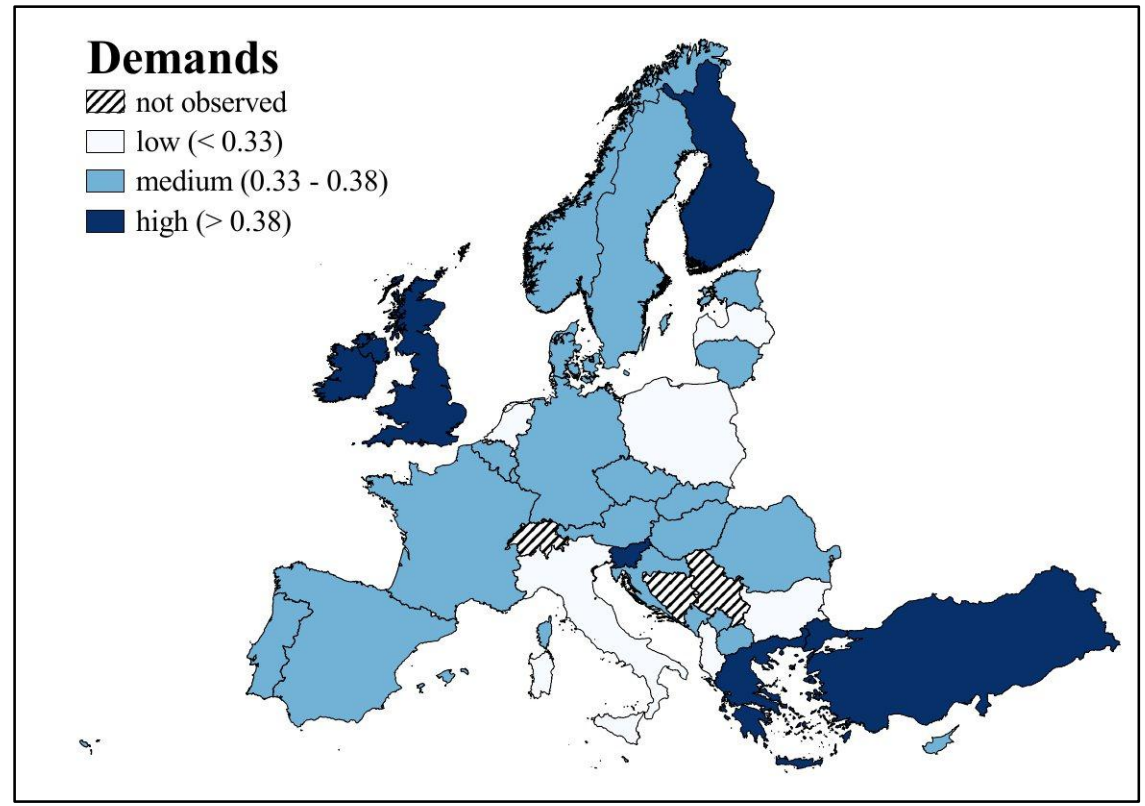

Figure 6. Demands 2010

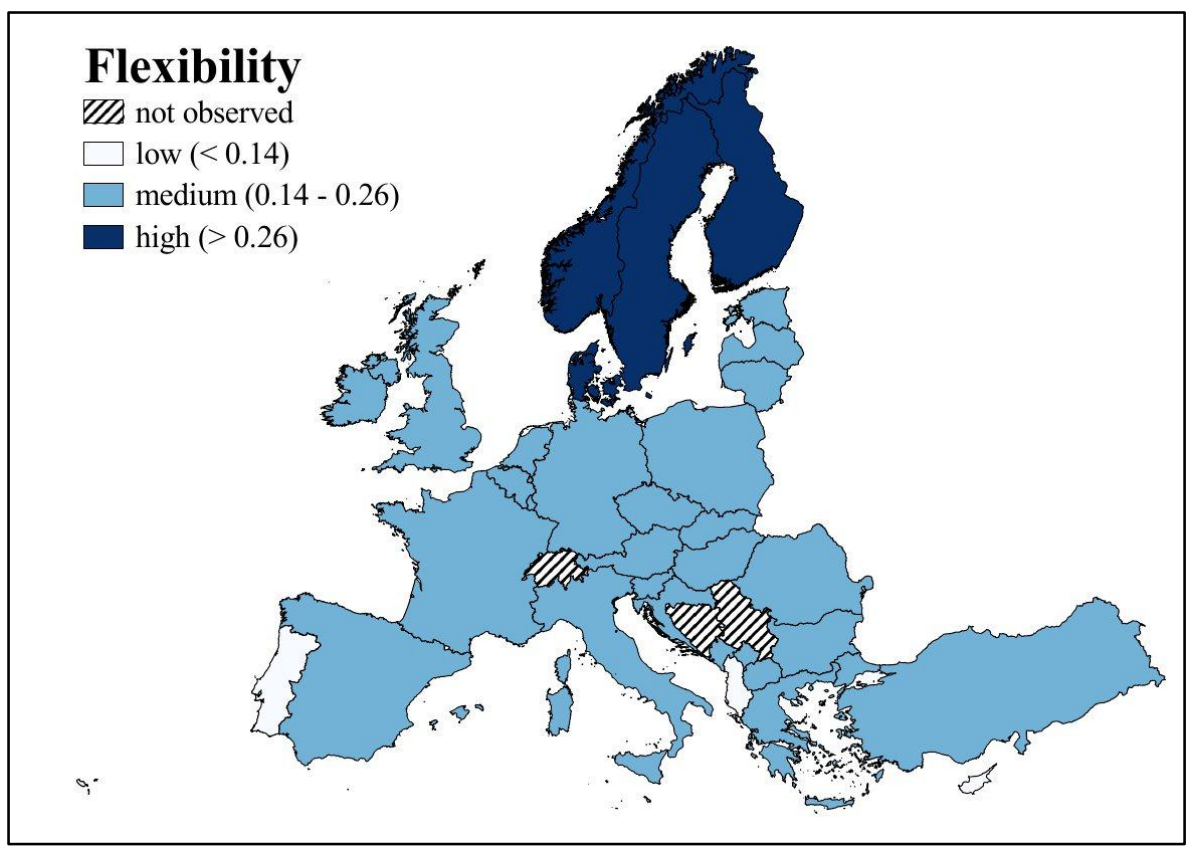

Figure 7. Flexibility 2010

Let us focus on the empirical results of the regression analyses for our specified model. Table 4 shows the results out of the multiple regression. There we find the regression results over the whole constructs as well as over their dimensions.

First of all, we address the interaction between well-being (WB) and the resources (RES), demands (DEM) and flexibility (FLEX). Thus it appears that higher resources lead significantly to a higher well-being and higher demands to a lower well-being. The flexibility has a low significant (at the $10 \%$ level) and a nearly negligible influence on well-being. This is also underpinned by the correlation analysis (see table 2), in which we found a first hint, that flexibility mainly acts on demands and then on resources. In other words: To increase the employees well-being it is efficient to reduce the demands and rise the resources.

Let us now focus in a more detailed way. Table 4 also illustrates the influence of the resources, demands and flexibility on the dimensions of well-being. Also in this context the flexibility has a very low effect on the dimensions. For somatic health (SomH) and satisfaction (Sat) this effect is high significant. A higher flexibility has a slightly negative impact on somatic health and a slightly positive one on satisfaction. The demands have a negative influence (with a high 
significant correlation) on our somatic health, psychological health (PsyH) and satisfaction. Thereby, the greatest effect is found for psychological health $(-0.357)$, followed by satisfaction $(-0.334)$ and somatic health $(-0.284)$. Also the resources exhibit high significant positive results in connection to employees well-being. Resources have a high positive effect on satisfaction $(0.598)$ followed by psychological health $(0.213)$. The impact on somatic health is rather low and shows a coefficient of 0.047 .

Similarly, we now consider the dimensions of the explanatory variables. We find high significant (at the $1 \%$ level) results for the dimensions social support \& participation (SocS), degrees of freedom (DeFre), requirements of qualification (Requ), workplace (Workpl), working activities (WorkA), time pressure (TimePres), routine tasks (RoutT), emotional strains and stress (EStress), numerical flexibility (Numerical) and wage flexibility (Wage) (Note 6). The working time (WorkTime) is significant at the 5\% level and the responsibility only at the $10 \%$ level. Each dimension of resources has a positive impact on well-being. The highest impact is found for social support \& participation (0.160), followed by degrees of freedom (0.092) and requirements (0.031). Apart from the dimension responsibility (which is not significant), also each dimension of the demands shows a negative impact on well-being. The highest coefficient is found for emotional strains and stress $(-0.136)$, followed by workplace $(-0.105)$, working activities $(-0.069)$, routine tasks (-0.041) and working time (-0.008). The dimensions of the construct flexibility seem to have a rather low impact on employees well-being. Both dimensions are highly significant. It seems that the numerical flexibility has a slightly negative effect on well-being $(-0.024)$ and the wage flexibility a slightly positive one $(0.046)$.

Table 5 displays the results for the least square dummy variable estimator by different groups.

In regression (1), we control for gender effects and find two interesting results: First a statistical highly significant (at the $1 \%$ level) difference between men's and women's well-being (men show a higher well-being than women) (Note 7) and second the demands have a greater impact on both men and women than flexibility (which is not significant), while the resources seem to be the same. Hence, both are significant at the $1 \%$ level, while the flexibility is not significant. To rise employees well-being, it is important to reduce their demands (-0.341) and increase their resources $(0.284)$.

Employees with a positive work-life-balance (regression (2)) show a significant higher well-being than those with a negative one (Note 8). The impact of demands on well-being decreases slightly to -0.282 as well as the impact of the resources $(0.266)$. Both dimensions remain high significantly (at the $1 \%$ level) and it is still important to reduce the demands and rise the resources to improve employees well-being.

Regression (3) controls for group effects concerning work-health-attitude. Our two sample $t$ test with equal variances (mean-comparison test) shows, that there is no significant difference between employees with a positive or neutral attitude but there is a clear and high significant difference to employees with a negative attitude. Employees with a negative attitude have lower well-being scores than the others. The influence of flexibility on well-being is not significant and negligible. While the influence of the resources and demands still remain as high significant but at a slightly lower level. To increase employees well-being it is still important to reduce the demands (-0.275) and raise the resources (0.226).

As it is shown in regression (4), the financial ease/security has an influence on employees well-being. If they are able to make ends meet very easily, the well-being is higher than in the opposite way. This is not really surprising but gives us an important information about the impact of resources, demands and flexibility. If we control for the financial ease/security, resources, demands and flexibility become high significant at the $1 \%$ level. Hence, the resources still have a positive influence on employees well-being and the demands a negative one. The impact of flexibility remains at a low but significant level. Here the flexibility shows a slightly negative impact on employees well-being.

If we view the mean values of well-being clustered by type of contract, the highest well-being is found for employees in apprenticeship (mean 0.747) followed by employees with an indefinite contract (mean 0.726), employees with an fixed term contract (mean 0.685), employees with no contract (mean 0.680) and employees with a temporary employment agency contract (mean 0.676). With the mean-comparison $t$ test we find no statistically significant differences in (the mean) well-being in dependence of the type of contract. This is also confirmed by the fact, that the coefficients of demands and flexibility do not differ to the results out of the ordinary least square estimation in table 4 . But it is of interest, that if we control for the type of contract, the resources become a slightly less influence on well-being (see regression (5) in table 5). This is a hint, that the type of contract influences the resources. This is also congruent with the JD-R model, in which the motivational-process starts with the availability of resources and some resources (e.g. participation) depends on the type of contract. 
Table 3. The ranking of the countries by well-being

\begin{tabular}{|c|c|c|c|c|}
\hline Position and country & Well-being & Resources & Demands & Flexibility \\
\hline 1 Ireland & 0.814 & 0.638 & 0.382 & 0.178 \\
\hline 2 Denmark & 0.786 & 0.755 & 0.339 & 0.325 \\
\hline 3 Kosovo & 0.786 & 0.650 & 0.368 & 0.142 \\
\hline 4 Malta & 0.784 & 0.686 & 0.337 & 0.162 \\
\hline 5 United Kingdom & 0.780 & 0.624 & 0.385 & 0.177 \\
\hline 6 Norway & 0.777 & 0.753 & 0.371 & 0.281 \\
\hline 7 Netherlands & 0.767 & 0.682 & 0.317 & 0.242 \\
\hline 8 Belgium & 0.754 & 0.602 & 0.354 & 0.248 \\
\hline 9 Luxembourg & 0.753 & 0.615 & 0.374 & 0.237 \\
\hline 10 Cyprus & 0.748 & 0.572 & 0.329 & 0.097 \\
\hline 11 Sweden & 0.748 & 0.669 & 0.368 & 0.293 \\
\hline 12 Spain & 0.744 & 0.554 & 0.364 & 0.140 \\
\hline 13 Austria & 0.742 & 0.638 & 0.358 & 0.258 \\
\hline 14 Germany & 0.729 & 0.562 & 0.368 & 0.235 \\
\hline 15 Poland & 0.721 & 0.547 & 0.308 & 0.197 \\
\hline 16 Greece & 0.717 & 0.511 & 0.387 & 0.145 \\
\hline 17 Finland & 0.716 & 0.702 & 0.392 & 0.334 \\
\hline 18 Romania & 0.713 & 0.597 & 0.337 & 0.172 \\
\hline 19 Albania & 0.713 & 0.601 & 0.314 & 0.130 \\
\hline 20 Montenegro & 0.709 & 0.507 & 0.346 & 0.181 \\
\hline 21 Macedonia & 0.702 & 0.570 & 0.380 & 0.144 \\
\hline 22 Italy & 0.698 & 0.539 & 0.313 & 0.184 \\
\hline 23 Bulgaria & 0.696 & 0.550 & 0.310 & 0.140 \\
\hline 24 Croatia & 0.694 & 0.575 & 0.349 & 0.170 \\
\hline 25 France & 0.691 & 0.553 & 0.378 & 0.240 \\
\hline 26 Portugal & 0.680 & 0.546 & 0.362 & 0.130 \\
\hline 27 Slovenia & 0.670 & 0.650 & 0.391 & 0.233 \\
\hline 28 Slovakia & 0.668 & 0.543 & 0.345 & 0.248 \\
\hline 29 Hungary & 0.658 & 0.579 & 0.352 & 0.157 \\
\hline 30 Czech Republic & 0.649 & 0.567 & 0.373 & 0.255 \\
\hline 31 Estonia & 0.642 & 0.655 & 0.344 & 0.228 \\
\hline 32 Turkey & 0.639 & 0.506 & 0.393 & 0.168 \\
\hline 33 Latvia & 0.626 & 0.666 & 0.326 & 0.163 \\
\hline 34 Lithuania & 0.595 & 0.549 & 0.329 & 0.175 \\
\hline
\end{tabular}

Discription: The ranking is due to the placement in well-being. In each case a high value means high well-being, resources, demands and flexibility and a low value means low well-being, resources, demands and flexibility. 
Table 4. Empirical Results - Multiple regression

\begin{tabular}{|c|c|c|c|c|c|}
\hline & WB & SomH & PsyH & Sat & WB \\
\hline Const. & $\begin{array}{l}0.662 * * * \\
(0.004)\end{array}$ & $\begin{array}{l}0.905 * * * \\
(0.004)\end{array}$ & $\begin{array}{l}0.727 * * * \\
(0.006)\end{array}$ & $\begin{array}{l}0.354 * * * \\
(0.006)\end{array}$ & $\begin{array}{l}0.686 * * * \\
(0.004)\end{array}$ \\
\hline RES & $\begin{array}{l}0.286 * * * \\
(0.005)\end{array}$ & $\begin{array}{l}0.0047 * * * \\
(0.005)\end{array}$ & $\begin{array}{l}0.213 * * * \\
(0.008)\end{array}$ & $\begin{array}{l}0.598 * * * \\
(0.008)\end{array}$ & \\
\hline SocS & & & & & $\begin{array}{l}0.160 * * * \\
(0.004)\end{array}$ \\
\hline DeFre & & & & & $\begin{array}{l}0.092 * * * \\
(0.005)\end{array}$ \\
\hline Requ & & & & & $\begin{array}{l}0.031 * * * \\
(0.004)\end{array}$ \\
\hline DEM & $\begin{array}{l}-0.323 * * * \\
(0.007)\end{array}$ & $\begin{array}{l}-0.284 * * * \\
(0.007)\end{array}$ & $\begin{array}{l}-0.357 * * * \\
(0.010)\end{array}$ & $\begin{array}{l}-0.334 * * * \\
(0.010)\end{array}$ & \\
\hline Workpl & & & & & $\begin{array}{l}-0.105 * * * \\
(0.007)\end{array}$ \\
\hline WorkA & & & & & $\begin{array}{l}-0.069 * * * \\
(0.005)\end{array}$ \\
\hline TimePres & & & & & $\begin{array}{l}-0.018 * * * \\
(0.003)\end{array}$ \\
\hline RoutT & & & & & $\begin{array}{l}-0.041 * * * \\
(0.003)\end{array}$ \\
\hline EStress & & & & & $\begin{array}{l}-0.136 * * * \\
(0.004)\end{array}$ \\
\hline Resp & & & & & $\begin{array}{l}0.005^{*} \\
(0.003)\end{array}$ \\
\hline WorkTime & & & & & $\begin{array}{l}-0.008 * * \\
(0.004)\end{array}$ \\
\hline FLEX & $\begin{array}{l}0.010^{*} \\
(0.006)\end{array}$ & $\begin{array}{l}-0.019 * * * \\
(0.005)\end{array}$ & $\begin{array}{l}-0.010 \\
(0.008)\end{array}$ & $\begin{array}{l}0.061 * * * \\
(0.008)\end{array}$ & \\
\hline Numerical & & & & & $\begin{array}{l}-0.024 * * * \\
(0.003)\end{array}$ \\
\hline Wage & & & & & $\begin{array}{l}0.046 * * * \\
(0.007)\end{array}$ \\
\hline $\mathrm{N}$ & 21,957 & 24,165 & 24,694 & 22,804 & 21,957 \\
\hline $\mathrm{R}^{2}$ & 0.197 & 0.091 & 0.081 & 0.248 & 0.247 \\
\hline Mean VIF & 1.08 & 1.08 & 1.08 & 1.08 & 1.30 \\
\hline
\end{tabular}

Discription: Heteroscedasticity-robust standard errors in parenthesis. For each variable the variance inflation factor (VIF) is below 10, so multicolinearity can be excluded. *, ** and *** indicate the $10 \%, 5 \%$ and $1 \%$ level of significance. WB ... Well-being, SomH ... Somatic health, PsyH ... Psychological health, Sat ... Satisfaction; RES ... Resources, SocS ... Social support \& Participation, DeFre ... Degrees of freedom, Requ ... Requirements of qualification; DEM ... Demands, Workpl ... Workplace, WorkA ... Working activities, TimePres ... Time pressure, RoutT ... Routine tasks, EStress ... Emotional strains and stress, Resp ... Responsibility,WorkTime ... Working time; FLEX ... Flexibility, Numerical ... Numerical flexibility, Wage ... Wage flexibility.

Finally, we control for some country effects. Table 6 presents the results for the LSDV by countries with Latvia as reference category. Apart from Lithuania, the countries differ significantly from Latvia. Nevertheless, the detected (between) country effects appear to be rather low (see also table 3). Probably, the inequality in well-being is higher in the within-country component, but to prove this further studies are needed. If we control for country effects, the coefficient of resources and demands do not significantly change. Nonetheless, it seems that flexibility have nearly no effect on employees well-being.

In summary, we can state that one of our hypotheses is refuted: The type of contract has no influence on well-being. The other hypotheses (see chapter 2.5) are confirmed by the analyses.

\section{Discussion and Conclusion}

As mentioned, we try to capture well-being in an efficient and appropriate way from the existing data set of the 5th EWCS. Thereby, our study is based on the perspective, that humans are not seen as only responding to their environment, instead they are seen as influencing and shaping their environment as well. Under this contemplation, work should allow further chances for the enhancement of the personality in the sense of Hacker, Ulich and Volpert (see Frese \& Zapf, 1994). Consequently, that means that work should not damage a person's mental and somatic health (see 
also Frese \& Zapf, 1994). Our findings about the impact on well-being provide employers, managers and decision makers with valuable information how to improve employees well-being, which is also important in times of high competition.

Table 5. Empirical Results - LSDV by groups

\begin{tabular}{|c|c|c|c|c|c|}
\hline $\begin{array}{c}\text { Dependent var. } \\
\text { Dummy }\end{array}$ & $\begin{array}{l}\text { (1) WB } \\
\text { Gender }\end{array}$ & $\begin{array}{l}\text { (2) WB } \\
\text { Work-Life- } \\
\text { Balance }\end{array}$ & $\begin{array}{l}\text { (3) WB } \\
\text { Work-Health- } \\
\text { Attitude }\end{array}$ & $\begin{array}{l}\text { (4) WB } \\
\text { Financial } \\
\text { ease }\end{array}$ & $\begin{array}{l}\text { (5) WB } \\
\text { Type of } \\
\text { contract }\end{array}$ \\
\hline Const. & $\begin{array}{l}0.690 * * * \\
(0.004)\end{array}$ & $\begin{array}{l}0.599 * * * \\
(0.005)\end{array}$ & $\begin{array}{l}0.544 * * * \\
(0.005)\end{array}$ & $\begin{array}{l}0.573 * * * \\
(0.006)\end{array}$ & $\begin{array}{l}0.662 * * * \\
(0.005)\end{array}$ \\
\hline RES & $\begin{array}{l}0.284 * * * \\
(0.005)\end{array}$ & $\begin{array}{l}0.266^{* * * *} \\
(0.005)\end{array}$ & $\begin{array}{l}0.268 * * * \\
(0.005)\end{array}$ & $\begin{array}{l}0.226 * * * \\
(0.005)\end{array}$ & $\begin{array}{l}0.283 * * * \\
(0.005)\end{array}$ \\
\hline DEM & $\begin{array}{l}-0.341 * * * \\
(0.007)\end{array}$ & $\begin{array}{l}-0.282 * * * \\
(0.007)\end{array}$ & $\begin{array}{l}-0.206 * * * \\
(0.007)\end{array}$ & $\begin{array}{l}-0.275^{* * * *} \\
(0.007)\end{array}$ & $\begin{array}{l}-0.323 * * * \\
(0.007)\end{array}$ \\
\hline FLEX & $\begin{array}{l}0.005 \\
(0.006)\end{array}$ & $\begin{array}{l}0.025 * * * \\
(0.006)\end{array}$ & $\begin{array}{l}0.009 * \\
(0.005)\end{array}$ & $\begin{array}{l}-0.024 * * * \\
(0.005)\end{array}$ & $\begin{array}{l}0.010^{*} \\
(0.006)\end{array}$ \\
\hline Female & $\begin{array}{l}-0.039 * * * \\
(0.002)\end{array}$ & & & & \\
\hline $\begin{array}{l}\text { Positive Work- } \\
\text { Life-Balance }\end{array}$ & & $\begin{array}{l}0.070 * * * \\
(0.003)\end{array}$ & & & \\
\hline Positive & & & $\begin{array}{l}0.116 * * * \\
(0.004)\end{array}$ & & \\
\hline Neutral & & & $\begin{array}{l}0.125^{* * *} * \\
(0.003)\end{array}$ & & \\
\hline Very easily & & & & $\begin{array}{l}0.168 * * * \\
(0.006)\end{array}$ & \\
\hline Easily & & & & $\begin{array}{l}0.162 * * * \\
(0.006)\end{array}$ & \\
\hline Fairly easily & & & & $\begin{array}{l}0.138 * * * \\
(0.006)\end{array}$ & \\
\hline $\begin{array}{l}\text { With some } \\
\text { difficulty }\end{array}$ & & & & $\begin{array}{l}0.088 * * * \\
(0.006) \\
0.038 * * *\end{array}$ & \\
\hline With difficulty & & & & $(0.006)$ & \\
\hline Apprenticeship & & & & & $\begin{array}{l}0.034 * * \\
(0.015)\end{array}$ \\
\hline Indefinite & & & & & $\begin{array}{l}0.005 \\
(0.004)\end{array}$ \\
\hline Fixed term & & & & & $\begin{array}{l}-0.019 * * * \\
(0.005)\end{array}$ \\
\hline $\begin{array}{l}\text { Temporary } \\
\text { employment }\end{array}$ & & & & & $\begin{array}{l}-0.010 \\
(0.009) \\
\end{array}$ \\
\hline $\mathrm{N}$ & 21,957 & 21,957 & 21,957 & 21,957 & 21,957 \\
\hline $\mathrm{R}^{2}$ & 0.209 & 0.218 & 0.291 & 0.268 & 0.199 \\
\hline Mean VIF & 1.08 & 1.12 & 1.20 & 2.69 & 1.38 \\
\hline
\end{tabular}

Discription: Heteroscedasticity-robust standard errors in parenthesis. For each variable the variance inflation factor (VIF) is below 10, so multicolinearity can be excluded. Constant corresponds to the reference category: (1) Male, (2) Negative Work-Life-Balance, (3) Negative attitude, (4) With great difficulty, (5) No contract. *, ** and *** indicate the $10 \%, 5 \%$ and $1 \%$ level of significance. 
Table 6. Empirical Results - LSDV by countries

\begin{tabular}{|c|c|c|}
\hline & \multicolumn{2}{|c|}{ WB } \\
\hline Const. & $0.549 * * *$ & $(0.007)$ \\
\hline RES & $0.281 * * *$ & $(0.005)$ \\
\hline DEM & $-0.329 * * *$ & $(0.007)$ \\
\hline FLEX & 0.007 & $(0.006)$ \\
\hline Ireland & $0.205^{* * *}$ & $(0.009)$ \\
\hline Kosovo & $0.189 * * *$ & $(0.010)$ \\
\hline United Kingdom & $0.181 * * *$ & $(0.008)$ \\
\hline Spain & $0.161 * * *$ & $(0.008)$ \\
\hline Luxembourg & $0.159 * * *$ & $(0.009)$ \\
\hline Belgium & $0.153 * * *$ & $(0.007)$ \\
\hline Greece & $0.152 * * *$ & $(0.009)$ \\
\hline Malta & $0.152 * * *$ & $(0.008)$ \\
\hline Cyprus & $0.151 * * *$ & $(0.009)$ \\
\hline Germany & $0.150 * * *$ & $(0.008)$ \\
\hline Sweden & $0.142 * * *$ & $(0.008)$ \\
\hline Norway & $0.136 * * *$ & $(0.008)$ \\
\hline Denmark & $0.136 * * *$ & $(0.008)$ \\
\hline Montenegro & $0.132 * * *$ & $(0.011)$ \\
\hline Austria & $0.130 * * *$ & $(0.009)$ \\
\hline Netherlands & $0.129 * * *$ & $(0.008)$ \\
\hline Poland & $0.127 * * *$ & $(0.009)$ \\
\hline Albania & $0.116 * * *$ & $(0.014)$ \\
\hline France & $0.112 * * *$ & $(0.008)$ \\
\hline Romania & $0.108 * * *$ & $(0.010)$ \\
\hline Croatia & $0.107 * * *$ & $(0.009)$ \\
\hline Italy & $0.107 * * *$ & $(0.009)$ \\
\hline Macedonia & $0.106 * * *$ & $(0.013)$ \\
\hline Portugal & $0.103 * * *$ & $(0.009)$ \\
\hline Bulgaria & $0.103 * * *$ & $(0.010)$ \\
\hline Finland & $0.094 * * *$ & $(0.008)$ \\
\hline Turkey & $0.081 * * *$ & $(0.008)$ \\
\hline Czech Republic & $0.078 * * *$ & $(0.010)$ \\
\hline Slovakia & $0.073 * * *$ & $(0.010)$ \\
\hline Slovenia & $0.069 * * *$ & $(0.008)$ \\
\hline Hungary & $0.065 * * *$ & $(0.009)$ \\
\hline Estonia & $0.022 * *$ & $(0.010)$ \\
\hline Lithuania & 0.008 & $(0.010)$ \\
\hline $\mathrm{N}$ & 21,957 & \\
\hline $\mathrm{R}^{2}$ & 0.261 & \\
\hline Mean VIF & 1.89 & \\
\hline
\end{tabular}

We find interesting geographical pattern. It appears that well-being is rather high in the northern part of West Europe and in North Europe. Low well-being is found for Turkey in the south and Estonia, Latvia, Lithuania, Hungary (which are located to the former eastern boundary) and for the Czech Republic in the east. We find high resources, which have a positive influence on well-being, in North Europe and low in South Europe. Interestingly, also high demands, which act negative on well-being, are found for the northern part of West Europe (United Kingdom and Ireland). Also the Human Development Index 2012 (HDI), which is an appropriate indicator to measure socio-economic development (capabilities), reveals a very high score for Ireland and the United Kingdom (see Malik et al., 2013). Nevertheless, permanently high demands lead to a reduced well-being. We also find high demands in South Europe. Flexibility is clearly high in North Europe, low in Portugal, Albania and Cyprus and medium in the other countries. Thereby, overall flexibility is neutral concerning well-being, whereas the impact in the individual case can be positive as well as negative. In order that the employees can benefit from the flexibilization, it is relevant that the employees can use flexible 
working conditions voluntarily, that they can act sovereign in terms of their flexibility and that a higher flexibility is accompanied by clear rules.

To improve employees well-being it is recommended to increase the resources and decrease the demands. Interestingly, the resources act mainly on the dimension of satisfaction, while demands have influence on somatic health, psychological (mental) health and satisfaction almost equally. Especially the dimensions social support \& participation as well as workplace and emotional strains and stress seem to be important for our well-being.

Concerning to our hypothesis, we find further interesting results. While there is a negative gender gap in well-being for women, a positive work-life-balance leads to a higher well-being as well as a higher financial ease/security do. Well it seems that there is also a self-fulfilling prophecy concerning to well-being. Employees who believe that work affects their health in a negative way, show a significant lower well-being. To affirm this finding it is necessary to prove, if they only believe that their work affects their health or if there really is an impact. Interestingly, there exists no significant difference in well-being concerning to the type of contract.

Finally, it must be noted, that our attempt to define the constructs well-being, demands, resources and flexibility out of the 5th EWCS is successful and we also gain interesting findings out of the data. Nevertheless, the limitations of the study should be mentioned. First of all, our model is very complex and we have to assume, that multiple interdependencies are possible. Second, we are dealing with survey data, the employees have judged themselves, a certain degree of subjectivity remains in the data and the data base is cross-section. Thus, our estimation by LSDV can only present a part of these interdependencies. Consequently, the causal relationships should be treated with some caution. And third, the data out of the 5th EWCS were collected in 2010. Maybe some conditions and results have changed since them. New data for the 6th EWCS were collected till December 2015 and will be available in 2016.

While the focus of this paper is to locate appropriate items for the definition of the constructs out of an existing data set, to give an overview of the cross-country heterogeneity and to detect impacts on well-being, we expect valuable additional insights when studying the development of well-being, resources, demands and flexibility, which can be done with the data out of the other European Working Conditions Surveys in a longer time perspective since 1991. Also further investigations to analyze the within- and between-country heterogeneity would be desirable. Moreover, it is of interest to improve the classification of the clusters (high, medium, low) to become able to make qualitative statements. This is of importance because organizations and employees are interested to know whether the specific characteristics of well-being, resources, demands and flexibility are on such a level that they should undertake action (see Demerouti \& Bakker, 2011).

\section{References}

Bakker, A., Demerouti, E., Boer, E., \& Schaufeli,W. (2003). Job demands and job resources as predictors of absence duration and frequency, Journal of Vocational Behavior, 62, 341-356.

Benach, J., Amable, M., Muntaner, C., \& Benavides, F. G. (2002). The consequences of flexible work for health: are we looking at the right place?, J. Epidemiol. Community Health, 56-6, 405-406.

Bernhard-Oettel, C., Sverke, M., \& Witte, H. (2005). Comparing three alternative types of employment with permanent full-time work: How do employment contract and perceived job conditions relate to health complaints?, Work \& Stress, 19-4, 301-318.

Bliesener, T., Dannecker, M., Dlugosch, G., Flor, D., Gstalter, H., Jäger, R., Kalb, P., Kanning, U., Lohaus, A., Mangold, R., Özdem, M., Pritzel, M., Rasch, T., Reiche, D., Reuter, S., Richter-Appelt, H., Rothenburg, C., Scharlan, I., Schmidbauer, W., Schütz, A., Sigusch, V., Spieß, E., \& Wenninger, G. (2009). Der Brockhaus Psychologie: Fühlen, Denken und Verhalten verstehen (2. vollständig überarbeitete Auflage). Mannheim: F.A. Brockhaus.

Bödeker, W., Friedel, H., Röttger, C., \& Schröer, A. (2002). Kosten arbeitsbedingter Erkrankungen, Schriftenreihe der Bundesanstalt für Arbeitsschutz und Arbeitsmedizin- Forschung - Fb 946, Dortmund, Berlin: BauA.

Burchell, B. (2009). Flexicurity as a moderator of the relationship between job insecurity and psychological well-being, Cambridge, Journal of Region, Economy and Society, 2, 365-378.

Cottini, E., \& Lucifora, C. (2010). Mental Health and Working Conditions in European Countries, Bonn: IZA, Discussion Paper, 4717.

Demerouti, E., \& Bakker, A. (2011). The Job Demands- Resources model: Challenges for future research, South African Journal of Industrial Psychology, 37, 1-9.

Demerouti, E., Bakker, A., \& Fried, Y. (2012). Work orientations in the job demands-resources model, Journal of Managerial Psychology, 27-6, 557-575.

Eckardstein, D., Lueger, G., Niedl, K., \& Schuster, B. (1995). Psychische Befindensbeeinträchtigung und Gesundheit 
im Betrieb: Herausforderung f ur Personalmanager und Gesundheitsexperten, München [u.a.]: Rainer Hampp.

Eurofound. (2007). Working conditions in the European Union: The gender perspective, Luxembourg: Office for Official Publications of the European Communities.

Eurofound (2009). A sector perspective on working conditions, Dublin: Eurofound.

Eurofound (2012). Working time and work-life balance in a life course perspective, Dublin: Eurofound.

Eurofound (2012a). Health and well-being at work: A report based on the fifth European Working Conditions Survey, Dublin: Eurofound.

Eurofound (2012b). Trends in job quality in Europe, Luxembourg: Publications Office of the European Union.

Ferrie, J. E. (2006). Gesundheitliche Folgen der Arbeitsplatzunsicherheit, in: Bandura, B., Schnellschmidt, H. and Vetter, C. (Hrsg.). Fehlzeiten-Report 2005, Arbeitsplatzunsicherheit und Gesundheit, Berlin [u.a.]: Springer, 93- 123.

Frauendorf, H., Caffier, G., Kaul, G., \& Wawrzinoszek, M. (1995). Modelluntersuchungen zur Erfassung und Bewertung der Wirkung kombinierter physischer und psychischer Belastungen auf Funktionen des HerzKreislaufsystems. In Schriftenreihe der Bundesanstalt f'ur Arbeitsmedizin und Arbeisschutz, BfHK 051, Bremerhaven: Wirtschaftsverlag NW.

Frese, M., \& Zapf, D. (1994). Action as the core of work psychology: A German approach, in: Triandis, H., Dunette, M. D. and Hough, L. (Eds.). Handbook of industrial and organizational psychology, Consulting Psychologists Press, Palto Alto, 4, 271-340.

Greenan, N., Kalugina, E., \& Walkowiak, E. (2010). Trends in quality of work in EU-15: Evidence from the European Working Conditions Survey (1995-2005). in: https://www.researchgate.net/publication/ 228467145_Trends_in _Quality_of_Work_in_the_EU-15_Evidence_from_the_European_Working_Conditions_Survey_1995-2005 [12.02.2016].

Greenan, N., Kalugina, E., \& Walkowiak, E. (2012). Has the Quality of Work Improved in the EU-15 between 1995 and 2005?, TEPP Working Paper, 2012-11.

Griffeth, R. W., Hom, P. W., \& Gärtner, S. (2000). A meta-Analysis of the Antecedents and Correlates of Employee Turnover: Update, Moderator Tests, and Research Implications for Next Millenium, Journal of Management, 26, 463-488.

Hacker, W. (1998). Allgemeine Arbeitspsychologie - Psychische Regulation von Arbeitstätigkeiten, Bern [u.a.]: Hans Huber.

Holman, D. (2011). An explanation of cross-national variation in call centre job quality using institutional theory, in: Work, Employment \& Society, 21-38.

Iwanowa, A. (2000). Was f'ur Arbeit braucht der Mensch? Sofia: Akademieverlag.

Iwanowa, A. (2004). Das Ressourcen-Anforderungs-Stressoren Modell, Bezüge zur Gesundheits- und Persönlichkeitsförderlichkeit in der Arbeitswelt, Habilitationsschrift an der LFU Innsbruck, Universit”at Innsbruck.

Iwanowa, A. (2006). Das Ressourcen-Anforderungen-Stressoren Modell, In Sachse, P. \& Weber, W.G. (Hrsg.). Psychologie der Arbeitstätigkeit, Bern: Huber, 265-283.

Iwanowa, A. (2012). Arbeitspsychologische Verfahren in der Evaluierung psychischer Belastungen am Arbeitsplatz, Institut für Psychologie, Leopold-Franzens Universität Innsbruck, Discussion Contribution, Forum Prävention 2012, Arbeitsgruppe Angewandte Psychologie, in AUVA: http://www.auva.at/mediaDB/878865_Iwanowa _Arbeitspsychologische_Verfahren_Evaluierung.pdf [08.01.2014].

Janßen, D., \& Nachreiner, F. (2004). Flexible Arbeitszeiten, Dortmund [u.a.]: Wirtschaftsverlag NW.

Karasek, R. A., \& Theorell, T. (1990). Healthy Work, New York: Basic Books.

Keller, B., \& Seifert, H. (2006). Atypische Beschäftigungsverhältnisse: Flexibilität, soziale Sicherheit und Prekarität, WSI Mitteilungen, 5, 235-240.

Kennedy, P. (2003). A Guide to Econometrics (5th Edition). MIT Press, Cambridge.

Klau, F., \& Mittelstadt, A. (1989). Labour Market Flexibility, OECD Economics and Statistics Department.

Lederbogen, F., Deuschle, M., \& Heuser, I. (1999). Depression - ein kardiovaskulärer Risikofaktor, Internist, Vol. 40, 1119-1121.

Leitner, K., \& Resch, M. (2005). Do the Effects of Job Stressors on Health Persist Over Time? A Longitudinal Study With Observational Stressor Measures, Journal of Occupational Health Psychology 2005, Vol. 10-1, 18-30. 
Leschke, J., \& Watt, A. (2008). Job quality in Europe, Brussels: ETUI-REHS.

Levie, L. (2002). Würze des Lebens oder Gifthauch des Todes?, Magazin Ausgabe 5-Stress lass nach, Bilbao: Europäische Agentur für Sicherheit und Gesundheitsschutz am Arbeitsplatz, 11-13.

Lorenz, E., \& Lundvall, B. A. (2011). Accounting for Creativity in the European Union: A multi-level analysis of individual competence, labour market structure, and systems of education and training, Cambridge Journal of Economics, 35, 269-294.

Lundenberg, U., Kadefors, R., Melin, B., Palmerud, G., Hassmen, P. L., Engström, M., \& Elfsberg, D. I. (1994). Psychophysiological stress and EMG activity of the trapezius muscle, International Journal of Behavioral Medicins, 1, 345-370.

Maintz, G., Ullsperger, P., Junghanss, G., \& Ertel, M. (2000). Psychische Arbeitsbelastung und Prävention von Muskel-Skeletterkrankungen, In Tagungsband: Gemeinsam gegen Muskel- und Skeletterkrankungen, Potsdam: Landesinstitut für Arbeitsschutz und Arbeitsmedizin, 52-57.

Malik, K., Kugler, M., Kovacevic, M., Bhattacharjee, S., Bonini, A., Calderon, C., Fuchs, A., Gaye, A., Konova, I., Minsat, A., Nayyar, S., Pineda., J., \& Wagle, S. (2013). Human Development Report 2013, The Rise of the South: Human Progress in a Diverse World, New York: UNDP.

Meissner, M. (1971). The Long Arm of the Job: A Study of Work and Leisure, Industrial Relations: A Journal of Economy and Society, 10(3), 239-260.

May, H., \& May, U. (2004). Lexikon der ökonomischen Bildung (5. aktualisierte und erweiterte Auflage). München/Wien: Oldenbourg.

Mayer, K. C. (2003). Depression als Risikofaktor f"ur k"orperliche Erkrankungen, in: http://www.neuro24.de/d9.htm [08.01.2014].

Meissner, M. (1971). The long arm of the job: a study of work and leisure, Industrial Relations, 10, 239-260.

Mohr, G., \& Semmer, N. K. (2002). Arbeit und Gesundheit: Kontroversen zu Person und Situationen, Psychologische Rundschau, 53(2), 77-84.

Origio, F., \& Pagani, L. (2009). Flexicurity and job satisfaction in Europe: The importance of perceived and actual job stability for well-being at work, Labour Economics, 16, 547-555.

Penninx, B. W. J. H., Beekman, A. T. F., Honig, A., Deeg, D. J. H., Schoevers, R.A. van Eijk, J. T. M., \& van Tilburg, W. (2001). Depression and Cardiac Mortality: Results from a Community-Based Longitudinal Study, ArchGenPsychiatry, 58, 221-227.

Poggi, A. (2010). Job satisfaction, working conditions and aspirations, Journal of Economic Psychology, 31(6), 936-949.

Porter, J. R., \& Purser, C. W. (2008). Measuring relative sub-national human development: An application of the United Nation's Human Development Index using geographic information systems, Journal of Economic and Social Measurement, 33, 253-269.

Puig-Barrachina, V., Vanroelen, Ch., Vives, A., Mart'inez, J. M., Muntaner, C., Levecque, K., Benach, J., \& Louckx, F. (2013). Measuring employment precariousness in the European working conditions survey: The social distribution in Europe, Work: A Journal of Prevention, Assessment and Rehabilitation, 00-2013, 1-19.

Richter, P., \& Fritz, S. (2006). "Weiche“ Faktoren methodisch erhärten, Mehrebenen-Evaluation von Maßnahmen der betrieblichen Gesundheitsförderung, in: Moldaschl, M. (2006). Immaterielle Ressourcen II. München: Hampp Verlag.

Rundell, J. R., \&Wise, M. G. (1996). Textbook of Consulation-Liasion Psychiatry, Washington, D.C.: Am. Psychiatric Press.

Schaufeli, W. B., \& Bakker, A.B. (2004). Job demands, job resources and their relationship with burnout and engagement: A multi-sample study, Journal of Organizational Behavior, 25, 293-315.

Sedlmeier, P., \& Renkewitz, F. (2008). Forschungsmethoden und Statistik in der Psychologie, München: Pearson.

Semmer, N., \& Mohr, G. (2001). Arbeit und Gesundheit: Konzepte und Ergebnisse der arbeitspsychologischen Stressforschung, Psychologische Rundschau, 52(3), 150-158.

Siegrist, J. (1996). Adverse health effects of high effort-low reward conditions at work, Journal of Occupational Health Psychology, 1, 27-43.

Smith, M., Burchell, B., Fagan, C., \& O’Brien, C. (2008). Job quality in Europe, Industrial Relations Journal, 39(6), 
586-603.

Tangian, A. S. (2007). Is flexible work precarious? A study based on the 4th European survey of working conditions 2005. WSI-Discussionspaper, Düsseldorf: Hans Böckler Stiftung, 153.

Tangian, A. S. (2007a). Is work in Europe decent? A study based on the 4th European survey of working conditions 2005, WSI-Diskussionspapiere, Düsseldorf: Hans Böckler Stiftung, 157.

Tangian, A. S. (2009). Decent work: indexing European working conditions and imposing workplace tax, Transfer: European Review of Labour and Research, 15, 527-556.

Tims, M., Bakker, A., \& Derks, D. (2013). The Impact of Job Crafting and Job Demands, Job Resources, and WellBeing, Journal of Occupational Health Psychology, 18-2, 230-240.

Ulich, E., \& Wuelser, M. (2004). Gesundheitsmanagement im Unternehmen, Wiesbaden: Gabler.

Ulich, E. (2011). Arbeitspsychologie (7. neu überarbeitete und erweiterte Auflage). Zürich: vdf.

Vobruba, G. (2006). Grundlagen der Soziologie der Arbeitsflexibilität, Berliner Journal für Soziologie, 16(1), 25-35.

Wittig-Goetz, U. (2006). Psychische Belastungen, in: http://www.ergo-online.de/ site.aspx?url=html/ gesundheitsvorsorge/psychische_belastungen_stress/psychische_belastungen.htm [26.04.2013].

Xanthopoulou, D., Bakker, A., Demerouti, E., \& Schaufeli, W. (2007). The Role of Personal Resources in the Job Demands-Resources Model, International Journal of Stress Management, 14(2), 121-141.

\section{Notes}

Note 1 . This is underpinned by many theoretical and empirical research in a wide variety of disciplines. See also e.g. Burchell (2009). Xanthopoulou et al. (2007). Ferrie (2006). Richter \& Fritz (2006). Wittig-Goetz (2006). Bernhard-Oettel, Sverke \& Witte (2005). Leitner \& Resch (2005). Bakker et al. (2003), Hacker (1998), Eckardstein, Lueger, Niedl \& Schuster (1995) and Frese \& Zapf (1994).

Note 2. This is underpinned by a various strand of literature concerning flexible modes of working (see e.g. Burchell, 2009; Origo \& Pagani, 2009; Tangian, 2007; Keller \& Seifert, 2006; Vobruba, 2006; Janßen \& Nachreiner, 2004).

Note 3. Fore more information about the European Working Condition Survey and specific data see Eurofound: http://www.eurofound.europa.eu/surveys/ewcs/2010/index.htm [24.04.2013].

Note 4. Based on usual conventions of psychology, we also consider a correlation $<0.1$ as too weak (see Sedlmeier \& Renkewitz, 2008).

Note 5. Cronbach's alpha is a key figure of the internal consistency of a scale and can reach values between 0 and 1 . The higher it is, the higher is the validity of the total scale. Considering our data basis, values over 0.6 can be considered as acceptable, values over 0.7 as good and values over 0.9 as excellent values.

Note 6. In accordance to Tangian (2007) the numerical flexibility is the variability of standard numbers and of standard distribution of working hours and the wage flexibility is the dependence of salaries and wages on labour market or competitive conditions (Tangian, 2007, p. 13-14).

Note 7 . Which is also confirmed by a mean-comparison two-sample $t$ test with equal variances.

Note 8 . Which is also confirmed by a mean-comparison two-sample $t$ test with equal variances. 


\section{Appendix}

For model specification we used questions from the 5th EuropeanWorking Conditions Survey. Thereby the specification is explained in chapter 2. The survey consists of nominal scaled and dichotomous questions/answers. To make them comparable, we recode each question/answer to 0 and 1, so that in each case a low value means low well-being, resources, demands and flexibility and a high value means high well-being, resources, demands and flexibility. The values below are already recoded (if necessary). Values for "DK/No opinion" and "Refusal" are considered as missings, so that at least our sample consists of 28,876 (out of 35,187 ) employees from 34 countries.

Well being (Cronbachs $\alpha=0.828$ )

\begin{tabular}{|c|c|c|c|}
\hline \multicolumn{4}{|c|}{ Physical health } \\
\hline $\mathrm{q} 68$ & How is your health in general? Would you say it is ... & 1: Very good & 1 \\
\hline \multirow[t]{6}{*}{ (216) } & & 2: Good & 1 \\
\hline & & 3: Fair & 0 \\
\hline & & 4: Bad & 0 \\
\hline & & 5: Very bad & 0 \\
\hline & & 8: DK/No opinion & . \\
\hline & & 9: Refusal & . \\
\hline$\overline{q 69 a}$ & Over the past 12 months, did you suffer from any of health problems? & 1: Yes & 0 \\
\hline \multirow[t]{3}{*}{ (217) } & Hearing problems? & 2: No & 1 \\
\hline & & 8: DK & . \\
\hline & & 9: Refual & . \\
\hline$\overline{q 69 b}$ & Over the past 12 months, did you suffer from any of health problems? & 1: Yes & 0 \\
\hline \multirow[t]{3}{*}{ (218) } & Skin problems? & 2: No & 1 \\
\hline & & 8: DK & . \\
\hline & & 9: Refual & . \\
\hline$\overline{q 69 c}$ & Over the past 12 months, did you suffer from any of health problems? & 1: Yes & 0 \\
\hline \multirow[t]{3}{*}{ (219) } & Backache? & 2: No & 1 \\
\hline & & 8: DK & . \\
\hline & & 9: Refual & . \\
\hline q69e & Over the past 12 months, did you suffer from any of health problems? & 1: Yes & 0 \\
\hline \multirow[t]{3}{*}{ (221) } & Muscular pains in lower limbs? & 2: No & 1 \\
\hline & & 8: DK & . \\
\hline & & 9: Refual & . \\
\hline$\overline{q 69 g}$ & Over the past 12 months, did you suffer from any of health problems? & 1: Yes & 0 \\
\hline \multirow[t]{3}{*}{ (223) } & Stomachache? & 2: No & 1 \\
\hline & & 8: DK & . \\
\hline & & 9: Refual & . \\
\hline $\mathrm{q69h}$ & Over the past 12 months, did you suffer from any of health problems? & 1: Yes & 0 \\
\hline \multirow[t]{3}{*}{ (224) } & Respiratory diffculties? & 2: No & 1 \\
\hline & & 8: DK & . \\
\hline & & 9: Refual & . \\
\hline$\overline{q 69 i}$ & Over the past 12 months, did you suffer from any of health problems? & 1: Yes & 0 \\
\hline \multirow[t]{3}{*}{ (225) } & Cardiovascular diseases? & 2: No & 1 \\
\hline & & 8: DK & . \\
\hline & & 9: Refual & \\
\hline$\overline{q 69 j}$ & Over the past 12 months, did you suffer from any of health problems? & 1: Yes & 0 \\
\hline \multirow[t]{3}{*}{ (226) } & Injury(ies)? & 2: No & 1 \\
\hline & & 8: DK & . \\
\hline & & 9: Refual & . \\
\hline q69n & Over the past 12 months, did you suffer from any of health problems? & 1: Yes & 0 \\
\hline \multirow[t]{3}{*}{ (230) } & Other? & 2: No & 1 \\
\hline & & 8: DK & . \\
\hline & & 9: Refual & . \\
\hline$\overline{\mathrm{q} 74 \mathrm{a}}$ & Over the past 12 months did you work, when you were sick? & 1: Yes & 0 \\
\hline \multirow[t]{4}{*}{ (239) } & & 2: No & 1 \\
\hline & & 7: I was not sick & 1 \\
\hline & & 8: DK/No opinion & . \\
\hline & & 9: Refual & . \\
\hline
\end{tabular}


Psychological health

q69d Over the past 12 months, did you suffer from any of health problems? 1: Yes

(220) Muscular pains in shoulders, neck and/or upper limbs?

2: No

0

8: DK

9: Refual

q69f Over the past 12 months, did you suffer from any of health problems? 1: Yes

(222) Headaches, eyestrain?

2: No

8: DK

9: Refual

q69k Over the past 12 months, did you suffer from any of health problems? 1: Yes

(227) Depression or anxiety?

2: No

8: DK

9: Refual

q691 Over the past 12 months, did you suffer from any of health problems? 1: Yes

(228) Overall fatigue?

2: No

8: DK

9: Refual

$\mathrm{q} 69 \mathrm{~m}$ Over the past 12 months, did you suffer from any of health problems? 1: Yes

(229) Insomnia or general sleep difficulties?

2: No

8: DK

9: Refual

ef4a How you have been feeling over the last two weeks -

1: All of the time

(268) I have felt cheerful and in good spirits

2: Most of the time

4: Less than half of the time

5: Some of the time

6: At no time

8: DK

9: Refusal

ef4b How you have been feeling over the last two weeks -

1: All of the time

(269) I have felt calm and relaxed

2: Most of the time

5: Some of the time

6: At no time

8: DK

9: Refusal

ef4c How you have been feeling over the last two weeks -

1: All of the time

(270) I have felt active and vigorous

2: Most of the time

5: Some of the time

6: At no time

8: DK

9: Refusal

ef4d How you have been feeling over the last two weeks -

(271) I woke up feeling fresh and rested

\begin{tabular}{ll} 
1: All of the time & 1 \\
2: Most of the time & 1 \\
3: More than half of the time & 1 \\
4: Less than half of the time & 0 \\
5: Some of the time & 0 \\
6: At no time & 0 \\
8: DK &. \\
9: Refusal & . \\
1: All of the time & 1 \\
2: Most of the time & 1 \\
3: More than half of the time & 0 \\
4: Less than half of the time & 0 \\
5: Some of the time & 0 \\
6: At no time & 0 \\
8: DK &. \\
9: Refusal &. \\
\hline
\end{tabular}

ef4e How you have been feeling over the last two weeks -

(272) My daily life has been lled with things that interest me

9: Refusal 
Satisfaction

q76 On the whole, are you very satised, satisfied, not very satisfied or

(242) not at all satisfied with working conditions in your main paid job?

$\begin{array}{ll}\text { 1: Very satisfied } & 1 \\ \text { 2: Satisfied } & 1 \\ \text { 3: Not very satisfied } & 0 \\ \text { 4: Not at all satisfied } & 0 \\ \text { 8: DK/No opinion } & \\ \text { 9: Refusal }\end{array}$

q77a How much do you agree or disagree with statements describing

1: Strongly disagree

(243) some aspects of your job - I might lose my job in the next 6 months?

2: Disagree

3: Neither agree nor disagree 0

4: Agree

5: Strongly agree

7: Not Applicable

8: DK

9: Refusal

q77b How much do you agree or disagree with statements describing

1: Strongly disagree 0

(244) some aspects of your job - I am well paid for the work I do?

$\begin{array}{ll}\text { 2: Disagree } & 0 \\ \text { 3: Neither agree nor disagree } & 0\end{array}$

$\begin{array}{ll}\text { 3: Neither agree nor disagree } & 0 \\ \text { 4: Agree } & 1\end{array}$

5: Strongly agree 1

7: Not Applicable

8: DK

9: Refusal

q77c How much do you agree or disagree with statements describing

1: Strongly disagree $\quad 0$

(245) some aspects of your job - My job offers good prospects for career

2: Disagree advancement?

3: Neither agree nor disagree 0

4: Agree

5: Strongly agree

7: Not Applicable

8: DK

9: Refusal

q77d How much do you agree or disagree with statements describing

1: Strongly disagree 0

(246) some aspects of your job - I feel 'at home' in this organisation?

2: Disagree 0

3: Neither agree nor disagree 0

4: Agree

5: Strongly agree

7: Not Applicable

8: DK

9: Refusal

q77e How much do you agree or disagree with statements describing

1: Strongly disagree 0

(247) some aspects of your job - I have very good friends at work

\begin{tabular}{ll} 
2: Disagree & 0 \\
3: Neither agree nor disagree & 0 \\
4: Agree & 1 \\
5: Strongly agree & 1 \\
7: Not Applicable & $\cdot$ \\
8: DK & $\cdot$ \\
9: Refusal &. \\
1: Strongly disagree & 0 \\
2: Disagree & 0 \\
3: Neither agree nor disagree & 0 \\
4: Agree & 1 \\
5: Strongly agree & 1 \\
7: Not Applicable &. \\
8: DK &. \\
9: Refusal &. \\
\hline
\end{tabular}


Resources (Cronbachs $\alpha=\mathbf{0 . 7 9 3 )}$

Social support \& Participation

q51a Select the response which best describes your work situation:

(163) Your colleagues help and support you

$\begin{array}{ll}\text { 1: Always } & 1 \\ \text { 2: Most of the time } & 1 \\ \text { 3: Sometimes } & 0 \\ \text { 4: Rarely } & 0 \\ \text { 5: Never } & 0 \\ \text { 7: Not Applicable } & 0\end{array}$

8: DK

9: Refusal

q51b Select the response which best describes your work situation:

(164) Your manager helps and supports you

1: Always 1

2: Most of the time 1

3: Sometimes 0

4: Rarely 0

5: Never 0

7: Not Applicable 0

8: DK

9: Refusal

q51c Select the response which best describes your work situation:

1: Always

(165) You are consulted before targets for your work are set

2: Most of the time 1

3: Sometimes 0

4: Rarely 0

5: Never 0

7: Not Applicable 0

8: DK

9: Refusal

q51d Select the response which best describes your work situation:

1: Always 1

(166) You are involved in improving the work organization or work processes of your department or organisation

2: Most of the time 1

3: Sometimes 0

4: Rarely 0

5: Never 0

7: Not Applicable 0

8: DK

9: Refusal

q51e Select the response which best describes your work situation:

1: Always

(167) You have a say in the choice of your working partners

2: Most of the time 1

3: Sometimes 0

4: Rarely 0

5: Never 0

7: Not Applicable $\quad 0$

8: DK

9: Refusal

q51o Select the response which best describes your work situation:

1: Always

2: Most of the time

(177) You can influence decisions that are important for your work you

3: Sometimes 0
can express your views about what is happening in the organisation?

4: Rarely

5: Never

7: Not Applicable $\quad 0$

8: DK

9: Refusal

q64 At your workplace, does management hold meetings in which you

1: Yes

2: No

8: DK/No opinion

9: Refusal

\begin{tabular}{|c|c|c|c|}
\hline \multirow{2}{*}{\multicolumn{4}{|c|}{ Degrees of freedom }} \\
\hline & & & \\
\hline $\mathrm{q} 50 \mathrm{a}$ & Are you able to choose or change your order of tasks? & 1: Yes & 1 \\
\hline \multirow[t]{3}{*}{$(160)$} & & 2: No & 0 \\
\hline & & 8: DK & . \\
\hline & & 9: Refusal & . \\
\hline $\mathrm{q} 50 \mathrm{~b}$ & Are you able to choose or change your methods of work & 1: Yes & 1 \\
\hline
\end{tabular}




\begin{tabular}{|c|c|c|c|}
\hline$(161)$ & & $\begin{array}{l}\text { 2: No } \\
\text { 8: DK } \\
\text { 9: Refusal }\end{array}$ & $\begin{array}{l}0 \\
\text {. }\end{array}$ \\
\hline $\begin{array}{l}\mathrm{q} 50 \mathrm{c} \\
(162)\end{array}$ & Are you able to choose or change your speed or rate of work? & $\begin{array}{l}\text { 1: Yes } \\
\text { 2: No } \\
\text { 8: DK } \\
\text { 9: Refusal }\end{array}$ & $\begin{array}{l}1 \\
0 \\
.\end{array}$ \\
\hline $\begin{array}{l}\text { q51f } \\
(168)\end{array}$ & $\begin{array}{l}\text { Select the response which best describes your work situation: } \\
\text { You can take a break when you wish }\end{array}$ & $\begin{array}{l}\text { 1: Always } \\
\text { 2: Most of the time } \\
\text { 3: Sometimes } \\
\text { 4: Rarely } \\
\text { 5: Never } \\
\text { 8: DK } \\
\text { 9: Refusal }\end{array}$ & $\begin{array}{l}1 \\
1 \\
0 \\
0 \\
0 \\
\text {. }\end{array}$ \\
\hline $\begin{array}{l}\text { q51g } \\
(169)\end{array}$ & $\begin{array}{l}\text { Select the response which best describes your work situation: } \\
\text { You have enough time to get the job done }\end{array}$ & $\begin{array}{l}\text { 1: Always } \\
\text { 2: Most of the time } \\
\text { 3: Sometimes } \\
\text { 4: Rarely } \\
\text { 5: Never } \\
\text { 8: DK } \\
\text { 9: Refusal }\end{array}$ & $\begin{array}{l}1 \\
1 \\
0 \\
0 \\
0 \\
.\end{array}$ \\
\hline $\begin{array}{l}\text { q51h } \\
(170)\end{array}$ & $\begin{array}{l}\text { Select the response which best describes your work situation: } \\
\text { Your job gives you the feeling of work well done }\end{array}$ & $\begin{array}{l}\text { 1: Always } \\
\text { 2: Most of the time } \\
\text { 3: Sometimes } \\
\text { 4: Rarely } \\
\text { 5: Never } \\
\text { 8: DK } \\
\text { 9: Refusal }\end{array}$ & $\begin{array}{l}1 \\
1 \\
0 \\
0 \\
0 \\
.\end{array}$ \\
\hline $\begin{array}{l}\text { q51i } \\
(171)\end{array}$ & $\begin{array}{l}\text { Select the response which best describes your work situation: } \\
\text { You are able to apply your own ideas in your work }\end{array}$ & $\begin{array}{l}\text { 1: Always } \\
\text { 2: Most of the time } \\
\text { 3: Sometimes } \\
\text { 4: Rarely } \\
\text { 5: Never } \\
\text { 8: DK } \\
\text { 9: Refusal }\end{array}$ & $\begin{array}{l}1 \\
1 \\
0 \\
0 \\
0 \\
\text {. }\end{array}$ \\
\hline $\begin{array}{l}\mathrm{q} 51 \mathrm{j} \\
(172)\end{array}$ & $\begin{array}{l}\text { Select the response which best describes your work situation: } \\
\text { You have the feeling of doing useful work }\end{array}$ & $\begin{array}{l}\text { 1: Always } \\
\text { 2: Most of the time } \\
\text { 3: Sometimes } \\
\text { 4: Rarely } \\
\text { 5: Never } \\
\text { 8: DK } \\
\text { 9: Refusal }\end{array}$ & $\begin{array}{l}1 \\
1 \\
0 \\
0 \\
0 \\
.\end{array}$ \\
\hline Requil & ements of qualification & & \\
\hline $\begin{array}{l}\mathrm{q} 49 \mathrm{a} \\
(154)\end{array}$ & $\begin{array}{l}\text { Generally, does your main paid job involve meeting precise quality } \\
\text { standards? }\end{array}$ & $\begin{array}{l}\text { 1: Yes } \\
\text { 2: No } \\
\text { 8: DK } \\
\text { 9: Refusal }\end{array}$ & $\begin{array}{l}1 \\
0 \\
.\end{array}$ \\
\hline $\begin{array}{l}449 b \\
(155)\end{array}$ & $\begin{array}{l}\text { Generally, does your main paid job involve assessing yourself the } \\
\text { quality of your own work? }\end{array}$ & $\begin{array}{l}\text { 1: Yes } \\
\text { 2: No } \\
\text { 8: DK } \\
\text { 9: Refusal }\end{array}$ & $\begin{array}{l}1 \\
0 \\
.\end{array}$ \\
\hline $\begin{array}{l}\mathrm{q} 49 \mathrm{e} \\
(158)\end{array}$ & Generally, does your main paid job involve complex tasks? & $\begin{array}{l}\text { 1: Yes } \\
\text { 2: No } \\
\text { 8: DK } \\
\text { 9: Refusal }\end{array}$ & $\begin{array}{l}1 \\
0 \\
.\end{array}$ \\
\hline $\begin{array}{l}\mathrm{q} 49 \mathrm{f} \\
(159)\end{array}$ & Generally, does your main paid job involve learning new things? & $\begin{array}{l}\text { 1: Yes } \\
\text { 2: No } \\
\text { 8: DK } \\
\text { 9: Refusal }\end{array}$ & $\begin{array}{l}1 \\
0 \\
.\end{array}$ \\
\hline $\begin{array}{l}\mathrm{q} 53 \\
(181)\end{array}$ & Does your job involve rotating tasks between yourself and colleagues? & $\begin{array}{l}\text { 1: Yes } \\
2: \text { No }\end{array}$ & $\begin{array}{l}1 \\
0\end{array}$ \\
\hline
\end{tabular}


8: DK/No opinion

9: Refusal

Demands (Cronbachs $\alpha=\mathbf{0 . 7 6 5 )}$

Workplace

q23a Are you exposed at work to

(96) vibrations from hand tools, machinery, etc. ?

$\begin{array}{ll}\text { 1: All of the time } & 1 \\ \text { 2: Almost all of the time } & 1 \\ \text { 3: Around } 3 / 4 \text { of the time } & 1 \\ \text { 4: Around half of the time } & 1 \\ \text { 5: Around } 1 / 4 \text { of the time } & 0 \\ \text { 6: Almost never } & 0 \\ \text { 7: Never } & 0 \\ \text { 8: DK } & \text {. } \\ \text { 9: Refusal } & 1 \\ \text { 1: All of the time } & 1 \\ \text { 2: Almost all of the time } & 1 \\ \text { 3: Around } 3 / 4 \text { of the time } & 1 \\ \text { 4: Around half of the time } & 1 \\ \text { 5: Around } 1 / 4 \text { of the time } & 0 \\ \text { 6: Almost never } & 0 \\ \text { 7: Never } & 0 \\ \text { 8: DK } & \text {. } \\ \text { 9: Refusal } & \end{array}$

q23b Are you exposed at work to

(97) noise so loud that you would have to raise your voice to talk to people?

1: All of the time 1

q23c Are you exposed at work to

2: Almost all of the time 1

(98) high temperatures which make you perspire even when not working?

3: Around 3/4 of the time

4: Around half of the time

5: Around $1 / 4$ of the time

6: Almost never

7: Never

8: DK

9: Refusal

q23d Are you exposed at work to

(99) low temperatures whether indoors or outdoors?

$\begin{array}{ll}\text { 1: All of the time } & 1 \\ \text { 2: Almost all of the time } & 1 \\ \text { 3: Around } 3 / 4 \text { of the time } & 1 \\ \text { 4: Around half of the time } & 1 \\ \text { 5: Around } 1 / 4 \text { of the time } & 0 \\ \text { 6: Almost never } & 0 \\ \text { 7: Never } & 0\end{array}$

8: DK

9: Refusal

q23e Are you exposed at work to

1: All of the time

(100) breathing in smoke, fumes, powder or dust etc.?

2: Almost all of the time 1

3: Around $3 / 4$ of the time 1

4: Around half of the time 1

5: Around $1 / 4$ of the time 0

6: Almost never 0

7: Never 0

8: DK

9: Refusal

q23f Are you exposed at work to

1: All of the time 1

(101) breathing in vapours such as solvents and thinners?

2: Almost all of the time 1

3: Around $3 / 4$ of the time 1

4: Around half of the time 1

5: Around $1 / 4$ of the time 0

6: Almost never 0

7: Never 0

8: DK

9: Refusal

q23g Are you exposed at work to

1: All of the time

1




\begin{tabular}{|c|c|c|c|}
\hline$(102)$ & $\begin{array}{l}\text { handling or being in skin contact with chemical products or } \\
\text { substances? }\end{array}$ & $\begin{array}{l}\text { 2: Almost all of the time } \\
\text { 3: Around } 3 / 4 \text { of the time } \\
\text { 4: Around half of the time } \\
\text { 5: Around } 1 / 4 \text { of the time } \\
\text { 6: Almost never } \\
\text { 7: Never } \\
\text { 8: DK } \\
\text { 9: Refusal }\end{array}$ & $\begin{array}{l}1 \\
1 \\
1 \\
0 \\
0 \\
0 \\
.\end{array}$ \\
\hline $\begin{array}{l}\mathrm{q} 23 \mathrm{~h} \\
(103)\end{array}$ & $\begin{array}{l}\text { Are you exposed at work to } \\
\text { tobacco smoke from other people? }\end{array}$ & $\begin{array}{l}\text { 1: All of the time } \\
\text { 2: Almost all of the time } \\
\text { 3: Around } 3 / 4 \text { of the time } \\
\text { 4: Around half of the time } \\
\text { 5: Around } 1 / 4 \text { of the time } \\
\text { 6: Almost never } \\
\text { 7: Never } \\
\text { 8: DK } \\
\text { 9: Refusal }\end{array}$ & $\begin{array}{l}1 \\
1 \\
1 \\
1 \\
0 \\
0 \\
0 \\
.\end{array}$ \\
\hline $\begin{array}{l}\mathrm{q} 23 \mathrm{i} \\
(104)\end{array}$ & $\begin{array}{l}\text { Are you exposed at work to } \\
\text { handling or being in direct contact with materials which can be } \\
\text { infectious, such as waste, bodily fluids, laboratory materials, etc? }\end{array}$ & $\begin{array}{l}\text { 1: All of the time } \\
\text { 2: Almost all of the time } \\
\text { 3: Around } 3 / 4 \text { of the time } \\
\text { 4: Around half of the time } \\
\text { 5: Around } 1 / 4 \text { of the time } \\
\text { 6: Almost never } \\
\text { 7: Never } \\
\text { 8: DK } \\
\text { 9: Refusal }\end{array}$ & $\begin{array}{l}1 \\
1 \\
1 \\
1 \\
0 \\
0 \\
0 \\
.\end{array}$ \\
\hline \multicolumn{4}{|c|}{ Working activities } \\
\hline $\begin{array}{l}\mathrm{q} 24 \mathrm{a} \\
(105)\end{array}$ & Does your main paid job involve - Tiring or painful positions & $\begin{array}{l}\text { 1: All of the time } \\
\text { 2: Almost all of the time } \\
\text { 3: Around } 3 / 4 \text { of the time } \\
\text { 4: Around half of the time } \\
\text { 5: Around } 1 / 4 \text { of the time } \\
\text { 6: Almost never } \\
\text { 7: Never } \\
\text { 8: DK } \\
\text { 9: Refusal }\end{array}$ & $\begin{array}{l}1 \\
1 \\
1 \\
1 \\
0 \\
0 \\
0 \\
.\end{array}$ \\
\hline $\begin{array}{l}\mathrm{q} 24 \mathrm{~b} \\
(106)\end{array}$ & Does your main paid job involve - Lifting or moving people & $\begin{array}{l}\text { 1: All of the time } \\
\text { 2: Almost all of the time } \\
\text { 3: Around } 3 / 4 \text { of the time } \\
\text { 4: Around half of the time } \\
\text { 5: Around } 1 / 4 \text { of the time } \\
\text { 6: Almost never } \\
\text { 7: Never } \\
\text { 8: DK } \\
\text { 9: Refusal }\end{array}$ & $\begin{array}{l}1 \\
1 \\
1 \\
1 \\
0 \\
0 \\
0\end{array}$ \\
\hline $\begin{array}{l}\mathrm{q} 24 \mathrm{c} \\
(107)\end{array}$ & Does your main paid job involve - Carrying or moving heavy loads & $\begin{array}{l}\text { 1: All of the time } \\
\text { 2: Almost all of the time } \\
\text { 3: Around } 3 / 4 \text { of the time } \\
\text { 4: Around half of the time } \\
\text { 5: Around } 1 / 4 \text { of the time } \\
\text { 6: Almost never } \\
\text { 7: Never } \\
\text { 8: DK } \\
\text { 9: Refusal }\end{array}$ & $\begin{array}{l}1 \\
1 \\
1 \\
1 \\
0 \\
0 \\
0\end{array}$ \\
\hline $\begin{array}{l}\text { q24d } \\
(108)\end{array}$ & Does your main paid job involve - Standing & $\begin{array}{l}\text { 1: All of the time } \\
\text { 2: Almost all of the time } \\
\text { 3: Around } 3 / 4 \text { of the time } \\
\text { 4: Around half of the time } \\
\text { 5: Around } 1 / 4 \text { of the time } \\
\text { 6: Almost never } \\
\text { 7: Never }\end{array}$ & $\begin{array}{l}1 \\
1 \\
1 \\
1 \\
0 \\
0 \\
0\end{array}$ \\
\hline
\end{tabular}




\begin{tabular}{|c|c|c|c|}
\hline & & \multicolumn{2}{|l|}{$\begin{array}{l}\text { 8: DK } \\
\text { 9: Refusal }\end{array}$} \\
\hline \multicolumn{4}{|c|}{ Time pressure } \\
\hline $\begin{array}{l}\mathrm{q} 42 \\
(141)\end{array}$ & $\begin{array}{l}\text { Over the last } 12 \text { months how often has it happened to you that you } \\
\text { have worked in your free time in order to meet work demands? }\end{array}$ & $\begin{array}{l}\text { 1: Nearly every day } \\
\text { 2: Once or twice a week } \\
\text { 3: Once or twice a month } \\
\text { 4: Less often } \\
\text { 5: Never } \\
\text { 7: Not applicable } \\
\text { 8: DK/No opinion } \\
\text { 9: Refusal }\end{array}$ & $\begin{array}{l}1 \\
1 \\
1 \\
1 \\
0 \\
0 \\
. \\
.\end{array}$ \\
\hline $\begin{array}{l}\mathrm{q} 45 \mathrm{a} \\
(145)\end{array}$ & Does your job involve working at very high speed? & $\begin{array}{l}\text { 1: All of the time } \\
\text { 2: Almost all of the time } \\
\text { 3: Around } 3 / 4 \text { of the time } \\
\text { 4: Around half of the time } \\
\text { 5: Around } 1 / 4 \text { of the time } \\
\text { 6: Almost never } \\
\text { 7: Never } \\
\text { 8: DK } \\
\text { 9: Refusal }\end{array}$ & $\begin{array}{l}1 \\
1 \\
1 \\
1 \\
0 \\
0 \\
0 \\
.\end{array}$ \\
\hline $\begin{array}{l}\mathrm{q} 45 \mathrm{~b} \\
(146)\end{array}$ & Does your job involve working to tight deadlines? & $\begin{array}{l}\text { 1: All of the time } \\
\text { 2: Almost all of the time } \\
\text { 3: Around } 3 / 4 \text { of the time } \\
\text { 4: Around half of the time } \\
\text { 5: Around } 1 / 4 \text { of the time } \\
\text { 6: Almost never } \\
\text { 7: Never } \\
\text { 8: DK } \\
\text { 9: Refusal }\end{array}$ & $\begin{array}{l}1 \\
1 \\
1 \\
1 \\
0 \\
0 \\
0\end{array}$ \\
\hline
\end{tabular}

Routine tasks

q24e Does your main paid job involve - Repetitive hand or arm movements 1: All of the time 1 (109)

2: Almost all of the time 1

3: Around $3 / 4$ of the time 1

4: Around half of the time 1

5: Around $1 / 4$ of the time 0

6: Almost never 0

7: Never 0

8: DK

9: Refusal

q44a Does your job involve short repetitive tasks of less than 1 minute?

1: Yes

(143)

2: No

8: DK

9: Refual

$\mathrm{q} 44 \mathrm{~b}$ Does your job involve short repetitive tasks of less than 10 minutes?

(144)

2: No

9: Refual

q49d Generally, does your main paid job involve monotonous tasks?

1: Yes

(157)

2: No

8: DK

9: Refual

\section{Emotional strains and stress}

q47 How often do you have to interrupt a task you are doing in order to (152) take on an unforeseen task?

$\begin{array}{ll}\text { 1: Very often } & 1 \\ \text { 2: Fairly often } & 1 \\ \text { 3: Occasionally } & 0 \\ \text { 4: Never } & 0 \\ \text { 8: DK/No opinion } & \text {. } \\ \text { 9: Refusal } & \text {. } \\ \text { 1: Yes } & 1 \\ \text { 2: No } & 0\end{array}$

(156) problems on your own? 


\begin{tabular}{|c|c|c|c|}
\hline & & $\begin{array}{l}\text { 8: DK } \\
\text { 9: Refual }\end{array}$ & \\
\hline q511 & Select the response which best describes your work situation: & 1: Always & 1 \\
\hline (174) & $\begin{array}{l}\text { Your job involves tasks that are in conflict with your personal } \\
\text { values }\end{array}$ & $\begin{array}{l}\text { 2: Most of the time } \\
\text { 3: Sometimes } \\
\text { 4: Rarely } \\
\text { 5: Never } \\
\text { 8: DK } \\
\text { 9: Refusal }\end{array}$ & $\begin{array}{l}1 \\
1 \\
0 \\
0 \\
.\end{array}$ \\
\hline $\mathrm{q} 51 \mathrm{n}$ & Select the response which best describes your work situation: & 1: Always & 1 \\
\hline$(176)$ & You experience stress in your work & $\begin{array}{l}\text { 2: Most of the time } \\
\text { 3: Sometimes } \\
\text { 4: Rarely } \\
\text { 5: Never } \\
\text { 8: DK } \\
\text { 9: Refusal }\end{array}$ & $\begin{array}{l}1 \\
1 \\
0 \\
0 \\
.\end{array}$ \\
\hline $\begin{array}{l}\mathrm{q} 51 \mathrm{p} \\
(178)\end{array}$ & $\begin{array}{l}\text { Select the response which best describes your work situation: } \\
\text { Your job requires that you hide your feelings }\end{array}$ & $\begin{array}{l}\text { 1: Always } \\
\text { 2: Most of the time } \\
\text { 3: Sometimes } \\
\text { 4: Rarely } \\
\text { 5: Never } \\
\text { 8: DK } \\
\text { 9: Refusal }\end{array}$ & $\begin{array}{l}1 \\
1 \\
1 \\
0 \\
0 \\
\text {. }\end{array}$ \\
\hline \multicolumn{4}{|c|}{ Responsibility } \\
\hline $\begin{array}{l}\mathrm{q} 52 \mathrm{a} \\
(179)\end{array}$ & $\begin{array}{l}\text { If you make mistakes in your work, could it cause: } \\
\text { Physical injury to other people? }\end{array}$ & $\begin{array}{l}\text { 1: Always } \\
\text { 2: Most of the time } \\
\text { 3: Sometimes } \\
\text { 4: Rarely } \\
\text { 5: Never } \\
\text { 8: DK } \\
\text { 9: Refusal } \\
\end{array}$ & $\begin{array}{l}1 \\
1 \\
1 \\
0 \\
0 \\
\text {. }\end{array}$ \\
\hline $\begin{array}{l}q 52 b \\
(180)\end{array}$ & $\begin{array}{l}\text { If you make mistakes in your work, could it cause: } \\
\text { Financial loss to your company? }\end{array}$ & $\begin{array}{l}\text { 1: Always } \\
\text { 2: Most of the time } \\
\text { 3: Sometimes } \\
\text { 4: Rarely } \\
\text { 5: Never } \\
\text { 8: DK } \\
\text { 9: Refusal }\end{array}$ & $\begin{array}{l}1 \\
1 \\
1 \\
0 \\
0\end{array}$ \\
\hline \multicolumn{4}{|c|}{ Working time } \\
\hline $\begin{array}{l}\mathrm{q} 32 \\
(126)\end{array}$ & $\begin{array}{l}\text { Normally, how many times a month do you work at night, } \\
\text { for at least } 2 \text { hours between } 10.00 \mathrm{pm} \text { and } 05.00 \mathrm{am} \text { ? }\end{array}$ & $\begin{array}{l}\text { 0: Never } \\
\text { 1- 31: Number of times } \\
\text { 88: DK/No opinion } \\
\text { 99: Refusal }\end{array}$ & $\begin{array}{l}0 \\
1\end{array}$ \\
\hline $\begin{array}{l}\mathrm{q} 33 \\
(127)\end{array}$ & $\begin{array}{l}\text { How many times a month do you work in the evening, } \\
\text { for at least } 2 \text { hours between } 6.00 \mathrm{pm} \text { and } 10.00 \mathrm{pm} ?\end{array}$ & $\begin{array}{l}\text { 0: Never } \\
\text { 1- 31: Number of times } \\
\text { 88: DK/No opinion } \\
\text { 99: Refusal }\end{array}$ & $\begin{array}{l}0 \\
1 \\
\text {. }\end{array}$ \\
\hline $\begin{array}{l}\mathrm{q} 34 \\
(128)\end{array}$ & How many times a month do you work on Sundays? & $\begin{array}{l}\text { 0: Never } \\
\text { 1- 5: Number of times } \\
\text { 88: DK/No opinion } \\
\text { 99: Refusal }\end{array}$ & $\begin{array}{l}0 \\
1\end{array}$ \\
\hline $\begin{array}{l}\mathrm{q} 35 \\
(129)\end{array}$ & How many times a month do you work on Saturdays? & $\begin{array}{l}\text { 0: Never } \\
\text { 1- 5: Number of times } \\
\text { 88: DK/No opinion } \\
\text { 99: Refusal }\end{array}$ & $\begin{array}{l}0 \\
1\end{array}$ \\
\hline $\begin{array}{l}\mathrm{q} 36 \\
(130)\end{array}$ & $\begin{array}{l}\text { How many times a month do you work more than } \\
10 \text { hours a day? }\end{array}$ & $\begin{array}{l}\text { 0: Never } \\
\text { 1- 31: Number of times } \\
\text { 88: DK/No opinion } \\
\text { 99: Refusal }\end{array}$ & $\begin{array}{l}0 \\
1\end{array}$ \\
\hline
\end{tabular}


Flexibility (Cronbachs $\alpha=\mathbf{0 . 6 7 6})$

\begin{tabular}{|c|c|c|c|}
\hline \multicolumn{4}{|c|}{ Numerical flexibility } \\
\hline $\begin{array}{l}\mathrm{q} 37 \mathrm{a} \\
(131)\end{array}$ & Do you work - The same number of hours every day? & $\begin{array}{l}\text { 1: Yes } \\
\text { 2: No } \\
\text { 8: DK } \\
\text { 9: Refual }\end{array}$ & $\begin{array}{l}0 \\
1 \\
.\end{array}$ \\
\hline $\begin{array}{l}\mathrm{q} 37 \mathrm{~b} \\
(132)\end{array}$ & Do you work - The same number of days every week? & $\begin{array}{l}\text { 1: Yes } \\
\text { 2: No } \\
\text { 8: DK } \\
\text { 9: Refual }\end{array}$ & $\begin{array}{l}0 \\
1 \\
.\end{array}$ \\
\hline $\begin{array}{l}\mathrm{q} 37 \mathrm{c} \\
(133)\end{array}$ & Do you work - The same number of hours every week? & $\begin{array}{l}\text { 1: Yes } \\
\text { 2: No } \\
\text { 8: DK } \\
\text { 9: Refual }\end{array}$ & $\begin{array}{l}0 \\
1 \\
. \\
.\end{array}$ \\
\hline $\begin{array}{l}\mathrm{q} 37 d \\
(134)\end{array}$ & Do you work - Fixed starting and finishing times? & $\begin{array}{l}\text { 1: Yes } \\
\text { 2: No } \\
\text { 8: DK } \\
\text { 9: Refual }\end{array}$ & $\begin{array}{l}0 \\
1 \\
.\end{array}$ \\
\hline \multicolumn{4}{|c|}{ Wage flexibility } \\
\hline $\begin{array}{l}\text { ef7b } \\
(276)\end{array}$ & $\begin{array}{l}\text { Thinking about your earnings from your main job, what do they } \\
\text { include: Piece rate or productivity payments? }\end{array}$ & $\begin{array}{l}\text { 1: Mentioned } \\
\text { 2: Not mentioned } \\
\text { 8: DK } \\
\text { 9: Refual }\end{array}$ & $\begin{array}{l}1 \\
0 \\
. \\
.\end{array}$ \\
\hline $\begin{array}{l}\text { ef7c } \\
(277)\end{array}$ & $\begin{array}{l}\text { Thinking about your earnings from your main job, what do they } \\
\text { include: Extra payments for additional hours of work/overtime? }\end{array}$ & $\begin{array}{l}\text { 1: Mentioned } \\
\text { 2: Not mentioned } \\
\text { 8: DK } \\
\text { 9: Refual }\end{array}$ & $\begin{array}{l}1 \\
0 \\
.\end{array}$ \\
\hline $\begin{array}{l}\text { ef7d } \\
(278)\end{array}$ & $\begin{array}{l}\text { Thinking about your earnings from your main job, what do they } \\
\text { include: Extra payments compensating for bad or dangerous working } \\
\text { conditions? }\end{array}$ & $\begin{array}{l}\text { 1: Mentioned } \\
\text { 2: Not mentioned } \\
\text { 8: DK } \\
\text { 9: Refual }\end{array}$ & $\begin{array}{l}1 \\
0 \\
\text {. }\end{array}$ \\
\hline $\begin{array}{l}\text { ef7e } \\
(279)\end{array}$ & $\begin{array}{l}\text { Thinking about your earnings from your main job, what do they } \\
\text { include: Extra payments compensating for Sunday work? }\end{array}$ & $\begin{array}{l}\text { 1: Mentioned } \\
\text { 2: Not mentioned } \\
\text { 8: DK } \\
\text { 9: Refual }\end{array}$ & $\begin{array}{l}1 \\
0 \\
.\end{array}$ \\
\hline $\begin{array}{l}\text { ef7f } \\
(280)\end{array}$ & $\begin{array}{l}\text { Thinking about your earnings from your main job, what do they } \\
\text { include: Other extra payments? }\end{array}$ & $\begin{array}{l}\text { 1: Mentioned } \\
\text { 2: Not mentioned } \\
\text { 8: DK } \\
\text { 9: Refual }\end{array}$ & $\begin{array}{l}1 \\
0 \\
.\end{array}$ \\
\hline $\begin{array}{l}\text { ef7g } \\
(281)\end{array}$ & $\begin{array}{l}\text { Thinking about your earnings from your main job, what do they } \\
\text { include: Payments based on the overall performance of the company } \\
\text { where you work? }\end{array}$ & $\begin{array}{l}\text { 1: Mentioned } \\
\text { 2: Not mentioned } \\
\text { 8: DK } \\
\text { 9: Refual }\end{array}$ & $\begin{array}{l}1 \\
0 \\
.\end{array}$ \\
\hline $\begin{array}{l}\text { ef7i } \\
(282)\end{array}$ & $\begin{array}{l}\text { Thinking about your earnings from your main job, what do they } \\
\text { include: Income from shares in the company your work for? }\end{array}$ & $\begin{array}{l}\text { 1: Mentioned } \\
\text { 2: Not mentioned } \\
\text { 8: DK } \\
\text { 9: Refual }\end{array}$ & $\begin{array}{l}1 \\
0 \\
.\end{array}$ \\
\hline $\begin{array}{l}\mathrm{ef} 7 \mathrm{j} \\
(283)\end{array}$ & $\begin{array}{l}\text { Thinking about your earnings from your main job, what do they } \\
\text { include: Advantages of other nature? }\end{array}$ & $\begin{array}{l}\text { 1: Mentioned } \\
\text { 2: Not mentioned } \\
\text { 8: DK } \\
\text { 9: Refual }\end{array}$ & $\begin{array}{l}1 \\
0 \\
.\end{array}$ \\
\hline $\begin{array}{l}\text { ef7k } \\
(284)\end{array}$ & $\begin{array}{l}\text { Thinking about your earnings from your main job, what do they } \\
\text { include: Other? }\end{array}$ & $\begin{array}{l}\text { 1: Mentioned } \\
\text { 2: Not mentioned } \\
\text { 8: DK } \\
\text { 9: Refual }\end{array}$ & $\begin{array}{l}1 \\
0 \\
.\end{array}$ \\
\hline
\end{tabular}

\section{(cc) EY}

This work is licensed under a Creative Commons Attribution 3.0 License. 